\title{
Identificación del conjunto monumental histórico en el casco antiguo de la ciudad de Santiago de Veraguas
}

\author{
Sebastián Ariel Aguilar Medina. ${ }^{1 *}$ \\ ${ }^{1}$ Profesor, Investigador, Universidad Católica Santa María La Antigua. \\ *Autor para correspondencia: arq.sebastianaguilar@yahoo.com
}

Recibido: 28 de febrero de 2019

Aceptado: 04 de abril de 2019

\begin{abstract}
Resumen
Esta investigación plasma la "Identificación del Conjunto Monumental Histórico en el Casco Antiguo de la ciudad de Santiago de Veraguas", desde su época Colonial (Siglo XVII), hasta la fecha, basándonos en la necesidad de la conservación y protección de la herencia arquitectónica.

Esta evaluación fue enfocada en las siguientes variables, Sistemas Constructivos utilizados, materiales y su procedencia, crecimiento poblacional y análisis de la misma, influencia de la población en el desarrollo urbano de las áreas estudiadas, fecha y construcción de edificaciones, estilos arquitectónicos, infraestructuras desde su creación a posibles proyecciones, desarrollo de planos y reconstrucción digital virtual de algunas edificaciones, identificación de fotos antiguas que revelan la evolución e historia de la ciudad.
\end{abstract}

Esta investigación está acompañada de una extensa labor gráfica, por medio de diseños, fotografías, planos, desarrollos urbanos que son de gran ayuda para conocer la evolución del lugar y su futura proyección. Estos productos son el resultado del procesamiento de información tomados en los documentos recomendadas por ICOMOS, como los principios para el análisis, conservación y restauración de las estructuras del Patrimonio histórico.

El resultado ofrece un trabajo teórico y gráfico, que integra la metodología de la investigación arquitectónica y la información historiográfica, que satisfactoriamente el desarrollo de la investigación.

Los resultados obtenidos en esta investigación pueden ser utilizada como material con base didáctica y técnica en futuras investigaciones de profesionales, estudiantes y para el uso cultural de toda la población panameña y a nivel internacional.

Palabras clave: Santiago, Veraguas, Patrimonio Arquitectónico. 
Invest. pens. crit. (ISSN 1812-3864)

Vol. 7, No. 1, enero- abril 2019

pp. $52-85$

\section{Introducción}

Uno de los grandes problemas palpable en el Casco Antiguo de la ciudad de Santiago de Veraguas, es la falta de conservación de las edificaciones patrimoniales de la ciudad, desde sus inicios hasta la actualidad, producto resultante de un proceso de deterioro acumulado en el tiempo y transformaciones provocadas por la adaptación a nuevos usos, por divisiones o ampliaciones de las obras sin consulta especializada, y por la influencia "modernizadora"

de la arquitectura de los últimos años en la ciudad de Santiago; lo que provoca la pérdida de los valores, $\mathrm{y}$, por ende, la autenticidad de las obras.

Identificando el problema a investigarse y debido a la urgencia de preservar el patrimonio Histórico con que aún se cuenta en el área antigua de la ciudad de Santiago se ha elaborado la propuesta para la delimitación del Conjunto Monumental Histórico en el Casco Antiguo de la ciudad de Santiago de Veraguas, con el interés de la conservación y protección de la herencia arquitectónica.

En la Carta de Venecia (1964), se define que "las obras monumentales de los pueblos, portadoras de un mensaje espiritual del pasado, representan en la vida actual el testimonio vivo de sus tradiciones seculares. La humanidad, que cada día toma conciencia de los valores humanos, las considera patrimonio común reconociéndose responsable de su salvaguardia frente a las generaciones futuras. Estima que es su deber transmitirlas en su completa autenticidad."

Para llegar al resultado de esta propuesta se estudiaron todos los periodos de desarrollo del Casco Antiguo de la ciudad de Santiago, Provincia de Veraguas desde el punto de vista históricoarquitectónico, y las variables que integran estas ciudades físicamente desde sus fundaciones hasta la fecha. Como se establece en el documento de ICOMOS, "las estructuras del patrimonio arquitectónico, tanto por su naturaleza como por su historia (en lo que se refiere al material y ensamblaje), están sometidas a una serie de dificultades de diagnóstico y restauración, que limitan la aplicación de las disposiciones normativas y las pautas vigentes en el ámbito de la construcción. Ello hace tan deseable como necesario formular unas recomendaciones que garanticen la aplicación de unos métodos racionales de análisis y restauración, adecuados a cada contexto cultural." (Principios para el análisis, conservación y restauración de las estructuras del Patrimonio Arquitectónico. ICOMOS.). basándonos en estos principios hemos realizado el análisis, investigación y propuesta de este estudio, tomando en cuenta el contexto histórico del Casco Antiguo de la ciudad de Santiago de Veraguas, con sus propias características, elementos arquitectónicos que marcaron el desarrollo y la fisionomía de esta desde su inicio hasta la fecha.

Estos principios fueron complementados con gran cantidad de documentación para llegar al producto final.

Tomando en cuenta el principio 1.2. * "el valor y la autenticidad del patrimonio arquitectónico no pueden fundamentarse en criterios predeterminados porque el respeto que merecen todas las culturas requiere que el patrimonio material de cada una de ellas sea considerado dentro del contexto cultural al que pertenece", la ciudad de Santiago tiene características muy especiales, desde su creación, tomando el punto de vista técnico, religioso y social. Fundado siguiendo los

patrones dictados por Pedrarias, como un poblado español, entre los cuales, desde sus inicios hasta la historia reciente, se mantuvo un desarrollo urbano que podemos ubicar como un modelo de "Teoría Concéntrica", según Burgess (1920), el cual se ha mantenido hasta nuestros días. Muestra de esto es que hasta la fecha las dos primeras calles trazadas en el periodo de 1636-1637, por el Lic. Martin Delgado y Llanos cura vicario (Molina Castillo, Mario José. 2013), aún son el Centro de la ciudad la cual actualmente es el Centro Comercial, a diferencia de Siglos anteriores (XVII, XVIII, XIX y principios del Siglo XX) donde era el centro residencial de la ciudad. Este cambio de Centro 
Invest. pens. crit. (ISSN 1812-3864)

Vol. 7, No. 1, enero- abril 2019

pp. $52-85$

Residencial a Centro Comercial dado a partir de los años '70 del Siglo XX, e incrementándose en los años '80 del mismo Siglo, permitió que por la modernización de las edificaciones, mejor acceso a la ciudad con la construcción de la Carretera interamericana y la industrialización de nuevos materiales de construcción, se permitiera de manera indiscriminada la destrucción en gran manera, no dada antes en esta ciudad a tal escala, del Patrimonio edificado del Casco Viejo de la ciudad de Santiago, herencia de los Siglos anteriores. Aunque ya anteriormente se habían dado algunos casos aislados de destrucción patrimonial, aunque no de parte de los pobladores santiagüeños, como fue la demolición de la Iglesia Colonial San Juan de Dios (1759), en los años 1938, para colocar en su lugar el Internado de Varones de la recién inaugurada Escuela Normal de Señoritas (hoy Escuela Normal Juan Demóstenes Arosemena), esta edificación era la más antigua en pie con la que contaba la ciudad para esta época, gran perdida y de la que hoy solo que el nombre que heredó la Plaza San Juan de Dios, ubicada frente a esta edificación.

Tomando esta importante información en cuenta proponemos tomar en cuenta dentro de la Delimitación del Casco Antiguo de la ciudad de Santiago de Veraguas, sus primeras calles (Calle del Calvario y Calle Real, hoy Avenida Central y Calle Segunda) e indicar sus nombres originales, los que cuales ya son pocos conocidos por los residentes y visitantes de la ciudad, como consecuencia de la pérdida de identidad, valoración, promulgación y conocimiento histórico actual en el sitio.

Estas calles, fueron en inicio, diseñadas para el tráfico de caballos y personas a pie, por lo cual no se planificó para su uso actual que es de autos, las cuales se ampliaron para la década de los años '20 con la integración de la Calle del Calvario hoy Avenida Central al sistema de la Carretera Nacional, lo cual cambió para siempre el uso y fisionomía de estas calles las que hoy no tienen el mismo uso de la Época Colonial. Estos datos complementan el valor y autenticidad de estos elementos como La Calle del Calvario (1637) actual Avenida Central, Calle Real (1637) actual Calle Segunda, la Plaza Mayor (1637), Plaza San Juan de Dios (1759), la Iglesia Santiago Apóstol (1700 aprox.) considerado dentro del contexto cultural único de la ciudad, su historia y desarrollo.

Aunque ya en nuestro país encontramos la identificación como Bien cultural de varios lugares como, el inscrito en 1980 de las Fortificaciones de la costa caribeña de Panamá: Portobelo y San Lorenzo, el Sitio arqueológico de Panamá Viejo y distrito histórico de Panamá, Bien cultural inscrito en 1997. En 1997, el Casco Antiguo de Panamá es incluido en la lista de sitios de patrimonios de la Humanidad por la UNESCO. El Casco Antiguo de la ciudad de Colón, se declara Conjunto monumental Histórico según la «Ley No.47 de 8 de agosto de 2002», el Conjunto monumental histórico de Calidonia y Ancón, Mediante Ley 33 de 2006. El Casco Viejo de Santiago de Veraguas tiene sus propias características y dentro de sus edificaciones ninguna cuenta con la protección por ley para evitar su destrucción como sucedió ya este año (2016), con el Hotel Santiago, edificación de casi 100 años, de principios de Siglo XX y algunas residencias de la misma fecha de Calle Segunda.

En Santiago solo encontramos, La Escuela Normal Juan Demóstenes Arosemena de Santiago, declarado monumento histórico nacional mediante Ley 54 de 12 de diciembre de 1984.

La mayor parte de las estructuras y edificaciones ubicadas en el área de estudio han sufrido modificaciones en varios periodos, pero al ser Santiago una ciudad relativamente joven (380 aprox.) edificaciones como la Iglesia Catedral Santiago Apóstol, la Plaza Mayor, Plaza San Juan de Dios ha sufrido modificaciones en varios periodos de su historia lo que no les quita el valor patrimonial con el que cuentan, cada cual aún conserva algún elemento de valor histórico. El único espacio casi intacto a través de los años, es el Callejón de Barañano, uno de los tantos que formaban una red de callejones que para el Siglo XIX y principio del XX, formaban parte de las vías de comunicación y servicio de la ciudad, es imprescindible que se rescate su carácter histórico. 
Invest. pens. crit. (ISSN 1812-3864)

Vol. 7, No. 1, enero- abril 2019

pp. $52-85$

Ya en Las Normas de Quito (1977), se indicaba dentro del punto III. Patrimonio Monumental y El Monumento Americano, "no es menos cierto que gran parte de este patrimonio, se ha arruinado irremediablemente en el curso de las últimas décadas o se encuentra hoy en trance inminente de perderse. Múltiples factores han contribuido y siguen contribuyendo a mermar las reservas de los bienes culturales de la mayoría de los países de Iberoamérica, pero es necesario reconocer que la razón fundamental de la destrucción progresivamente acelerada de ese potencial de riqueza, radica en la carencia de una política oficial capaz de imprimir eficacia practica a las medidas proteccionistas vigentes y de promover la revalorización del patrimonio monumental en función del interés público y para beneficio económico de la nación.” Es el caso específico identificado en el área de estudio, al cual se ha deteriorado grandemente, no solo en las estructuras desaparecidas de la época Colonial, sino también en el deterioro de las más recientes, y la falta de medidas para la protección de la herencia arquitectónica, con excepción de algunos intentos actuales en el tema.

\section{Delimitación}

Proponemos la identificación del Conjunto Monumental de la Ciudad de Santiago de Veraguas desde Conclusiones.

El análisis de la problemática a la cual se ha enfrentado por años las edificaciones del área de estudio, en dicho contexto permitió agrupar posibles causas que inciden en la pérdida de gran parte de la herencia arquitectónica del Casco Viejo de Santiago de Veraguas y que debemos evitar. Entre ellas encontramos:

- La constante y acelerada alteración y destrucción del patrimonio arquitectónico del siglo XX, más acentuado a partir de la segunda mitad, acabando en mayor medida el aporte dejado del período colonial a la identidad regional.

- Falta de valoración y desconocimiento de la identidad histórica y cultural de la arquitectura de la ciudad, de parte de los residentes y visitantes de la misma, a través de la historia.

- Los grandes cambios sociales y de fisionomía arquitectónica, sin planificación desde sus inicios, por lo cual hemos perdido edificaciones de gran valor.

- Manejo y conservación casi nulo, del patrimonio arquitectónico por parte de los organismos e instituciones locales y nacionales en el área de estudio.

Tomando en cuenta los aspectos planteados con anterioridad, es urgente una solución a la problemática evidente:

- La necesidad de delimitar el Casco Antiguo de la ciudad de Santiago de Veraguas, para que por medio de leyes proteja las infraestructuras con valor histórico.

-Estas propuestas pueden ser a largo y corto plazo y que sirvan a su vez de referencias para futuras investigaciones y con objetivos académicos a su vez, en el ámbito de la arquitectura, el urbanismo o cualquier rama que pueda servirse de la misma.

-También puede ser un importante aporte al turismo ordenado de nuestra ciudad. En este caso indica en Las Normas de Quito (1977), "los valores propiamente culturales no se desnaturalizan ni comprometen al vincularse con los intereses turísticos y, lejos de ello, la mayor atracción que conquistan los monumentos y la afluencia creciente de admiradores foráneos, contribuyen a afirmar la conciencia de su importancia y significación nacionales. Un monumento restaurado adecuadamente, un conjunto urbano puesto en valor, constituyen no solo una lección viva de historia sino un legítimo motivo de dignidad nacional..." por lo cual proponemos esta integración entre historia y turismo en el área de estudio. 
Invest. pens. crit. (ISSN 1812-3864)

Vol. 7, No. 1, enero- abril 2019

pp. $52-85$

-En la ciudad de Santiago, provincia de Veraguas se localizan escasas investigaciones sobre arquitectura y urbanismo del Casco Antiguo y normas para su protección. Siendo así, se evidencia la necesidad de ampliar estudios sobre el tema en esta ciudad, con la idea de generar una visión más amplia, en términos historiográficos, de la realidad arquitectónica de Santiago.

-Siguiendo el principio 1.1. (Principios para el análisis, conservación y restauración de las estructuras del Patrimonio Arquitectónico. ICOMOS.), "La conservación, consolidación y restauración del patrimonio arquitectónico requieren un tratamiento multidisciplinar" por lo cual la propuesta de limitar el área física del Casco Antiguo de la ciudad de Santiago es solo el primer paso, luego se debe mantener una continua supervisión y verificación de las intervenciones en las estructuras construidas en el área de estudio, una Junta Técnica, conformada por profesionales de diferentes ramas para conservar y tomar las mejores decisiones en el área de estudio, algo que no se ha tenido en ningún periodo de la historia de la ciudad.

- también Las Normas de Quito (1977), indican que "del seno de la comunidad puede y debe surgir la voz de alarma y la acción vigilante y previsora. El fomento de agrupaciones cívicas pro-defensa del patrimonio, cualquiera que fuese su denominación y composición, ha dado excelentes resultados, especialmente en localidades que no disponen aún de regulación urbanística y donde la acción protectora a nivel nacional resulta débil o no siempre eficaz"

* (Principios para el análisis, conservación y restauración de las estructuras del Patrimonio Arquitectónico. ICOMOS.).

\section{Agradecimientos}

Agradecemos a la Universidad Católica Santamaría La Antigua, Vicerrectoría de Investigación y Postgrado, por su apoyo, en la asesoría técnica y por brindarnos la oportunidad de ser parte del Programa de Fomento a la Investigación. El Dr. Wong y Magister Rubén Díaz por sus continuos aportes y tiempo dedicado al desarrollo del proyecto. 
Invest. pens. crit. (ISSN 1812-3864)

Vol. 7, No. 1, enero- abril 2019

pp. $52-85$

\section{Imágenes}

\section{Delimitación del Casco Antiguo de Santiago de Veraguas.}

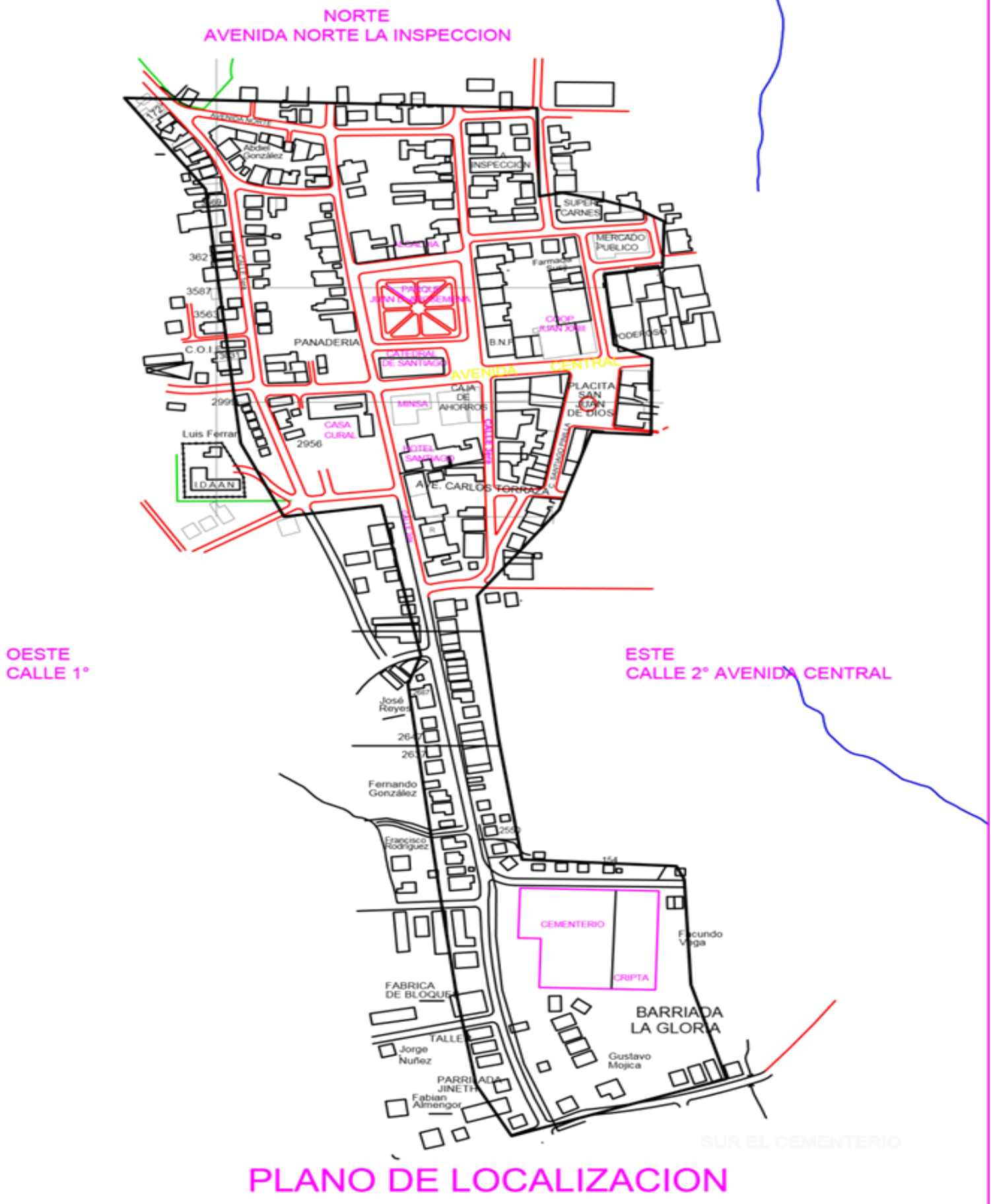


Invest. pens. crit. (ISSN 1812-3864)

Vol. 7, No. 1, enero- abril 2019

pp. $52-85$

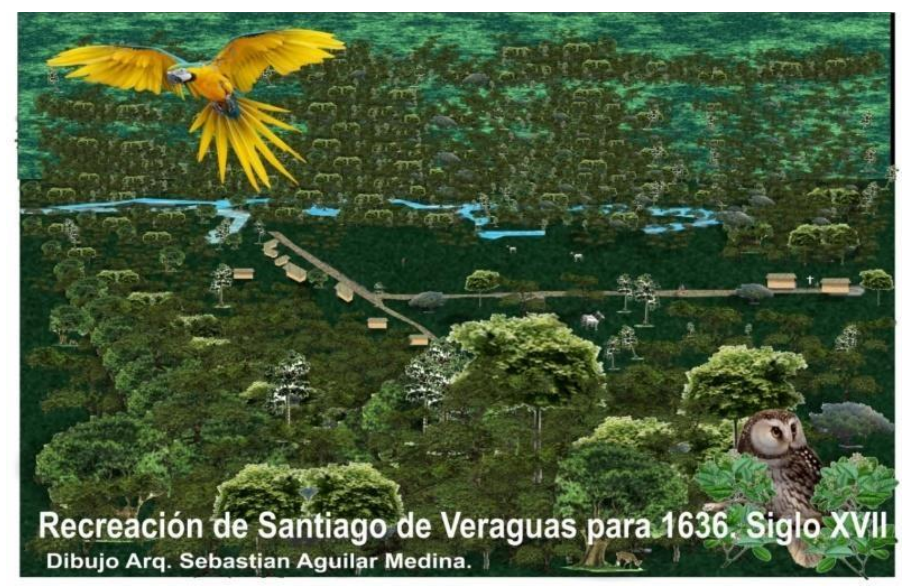

Ilustración 1. Recreación aproximada de la ciudad de Santiago 1,636. Arquitecto Sebastián Aguilar.

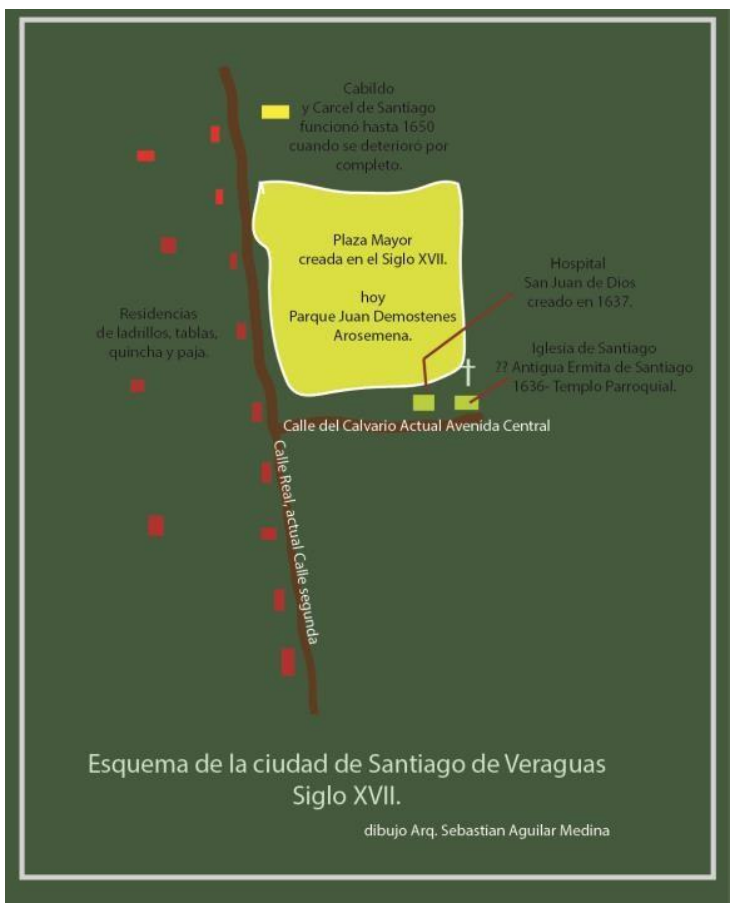

Ilustración 2. Plano Recreando la ciudad de Santiago Siglo XVII. Arquitecto Sebastián Aguilar. 
Invest. pens. crit. (ISSN 1812-3864)

Vol. 7, No. 1, enero- abril 2019

pp. $52-85$

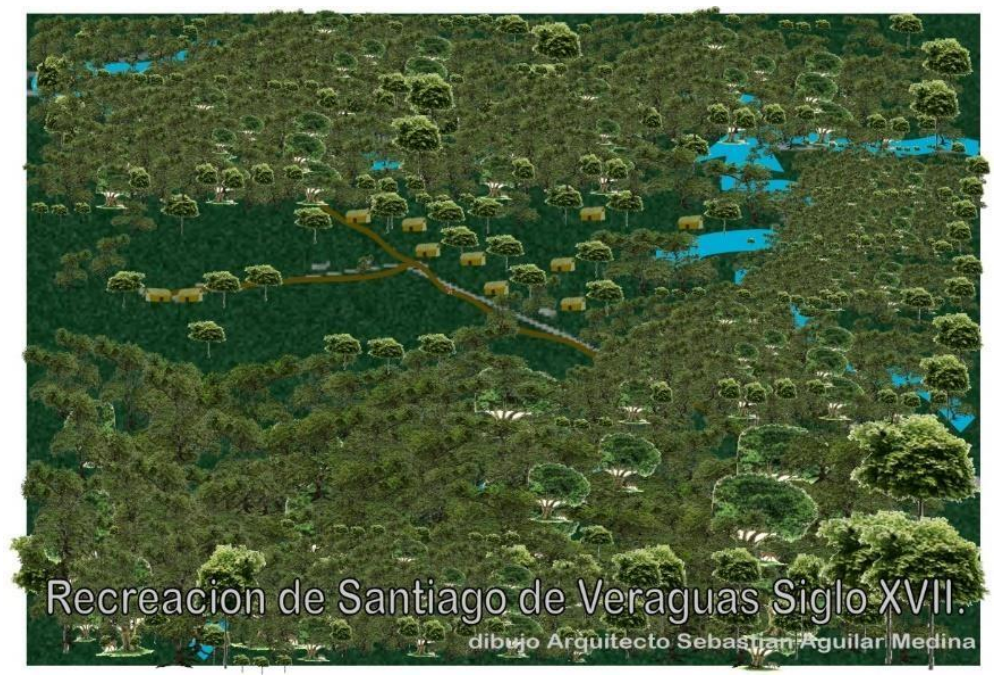

Ilustración 3. Recreación aproximada de la ciudad de Santiago Siglo XVII. Arquitecto Sebastián Aguilar.

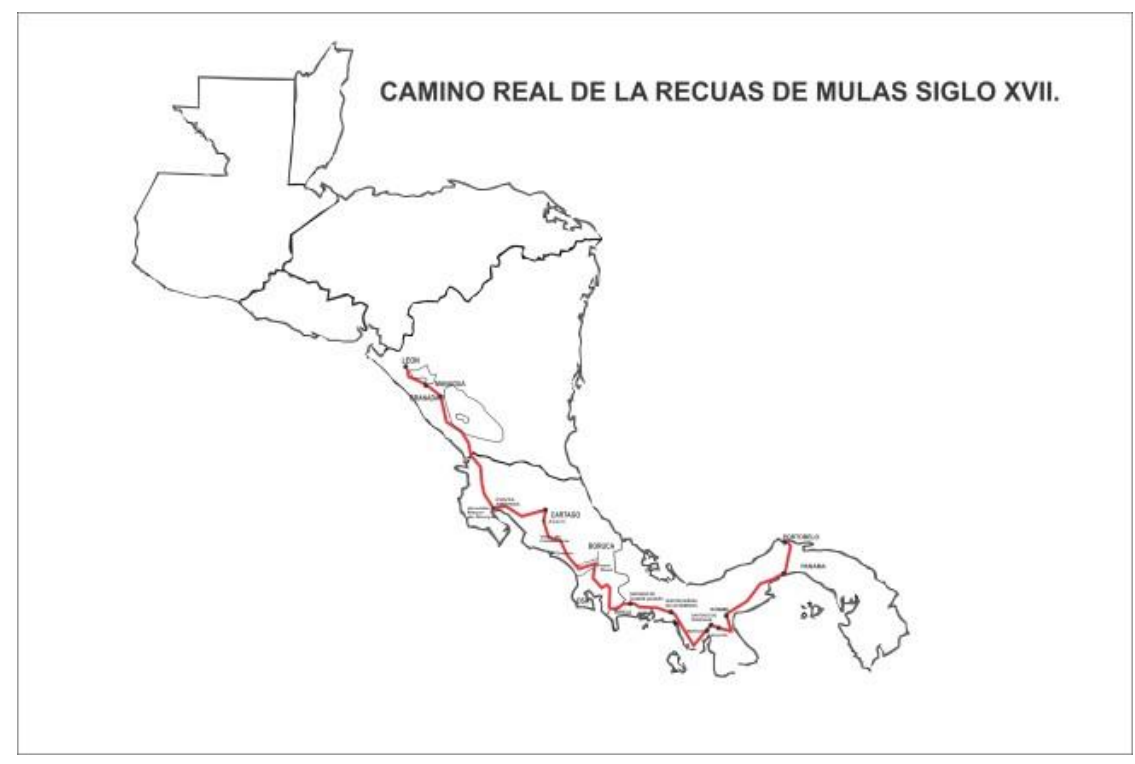

Ilustración 4. Camino Real de Recuas de Mulas. Dibujo Arquitecto Sebastián Aguilar. 


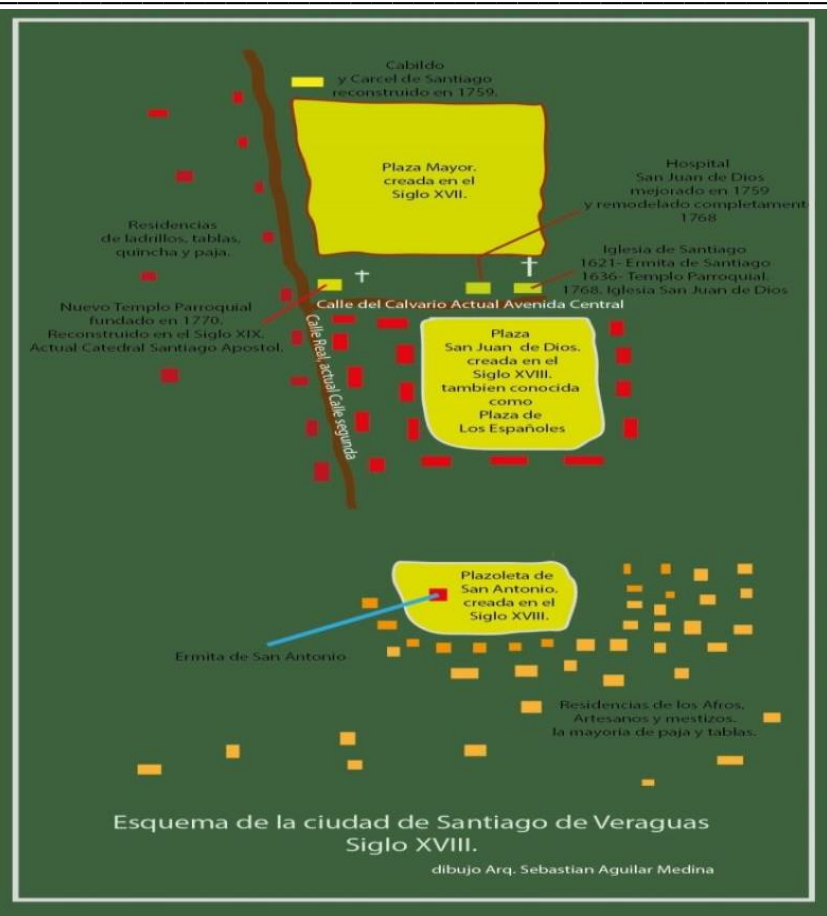

Ilustración 5. Plano de recreación de la Ciudad de Santiago en el Siglo XVIII. Arquitecto Sebastián Aguilar.

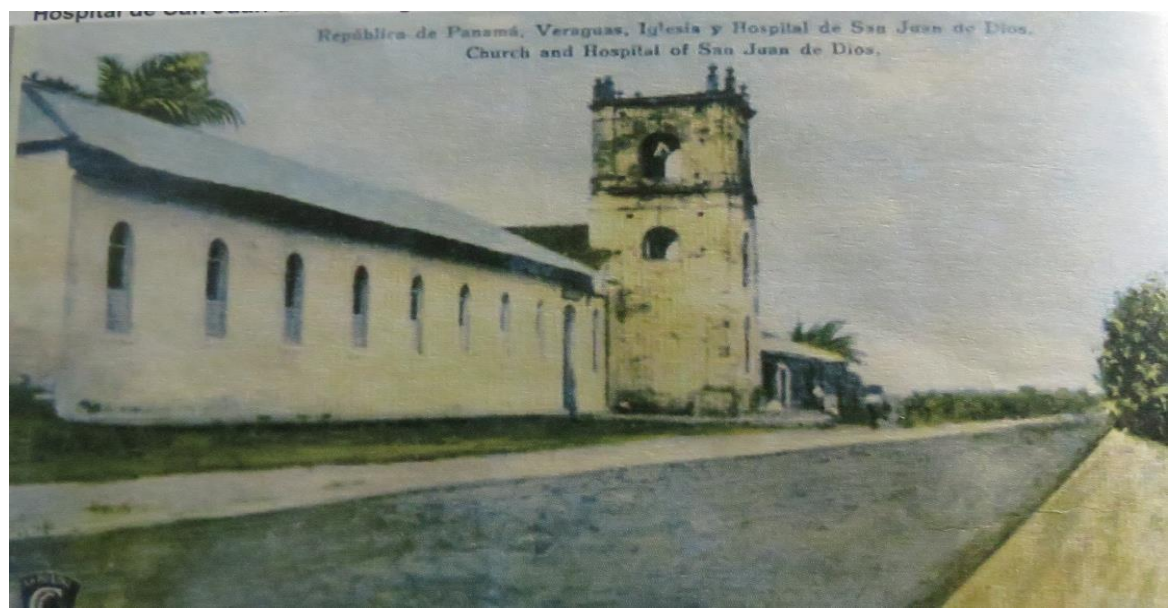

Ilustración 6. Hospital San Juan de Dios, reconstruido en 1759 y el pavimentado de las calles obras del Gobernador de Veragua Feliz Francisco Bejarano, Siglo XVIII. Tomado del libro Mario José Molina, Veragua: Tierra de Colón y Urracá. 
Invest. pens. crit. (ISSN 1812-3864)

Vol. 7, No. 1, enero- abril 2019

pp. $52-85$

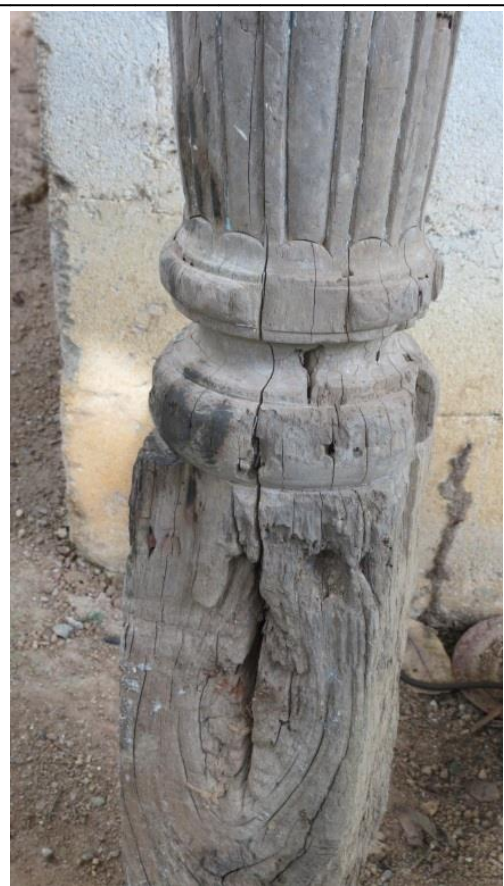

Ilustración 7. Trabajos de fuerte influencia barroca elaborados en los templos existentes a la izquierda escultura de los altares de la Iglesia San Francisco de la Montaña Siglo XVIII y a la derecha detalle de antigua columna del Altar principal de la Iglesia

\section{Catedral}

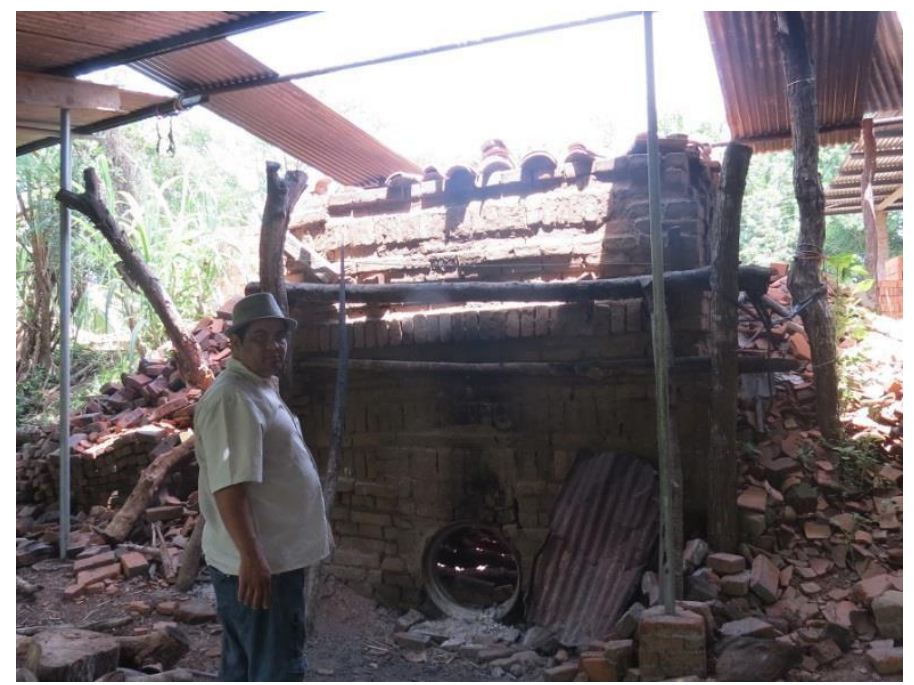

Ilustración 8. Horno para cocer Ladrillos y tejas. Foto tomada en Fábrica de Ladrillos en E1 Limón de Chupampa, Herrera, Arq. Aguilar. 


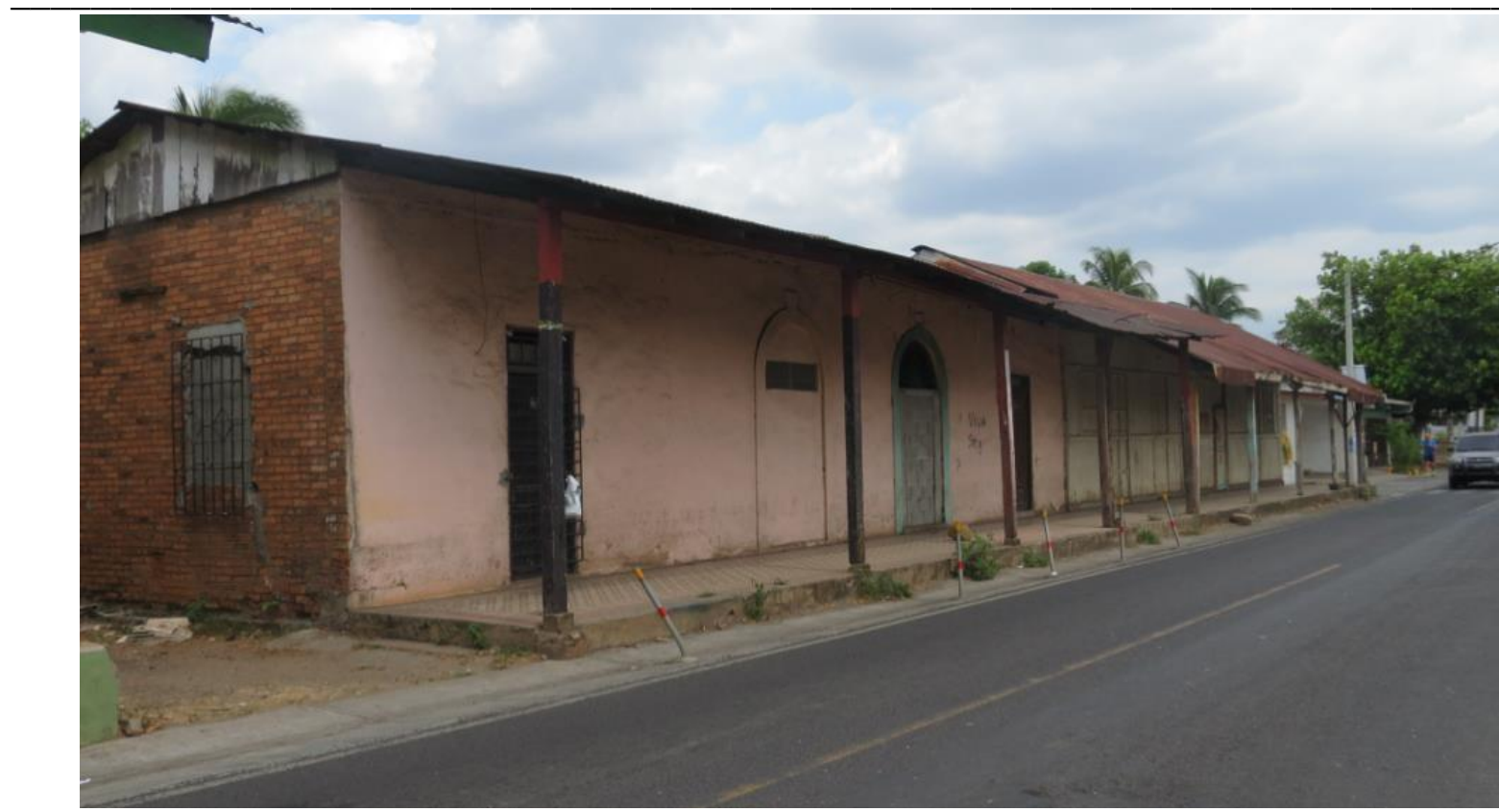

Ilustración 9. Casas de ladrillo aparecen en la segunda mitad del Siglo XVIII, en la ciudad de Santiago. Ejemplo Casa Familia Álvarez, inicio de Siglo XX. Foto Arq.

Sebastián Aguilar.

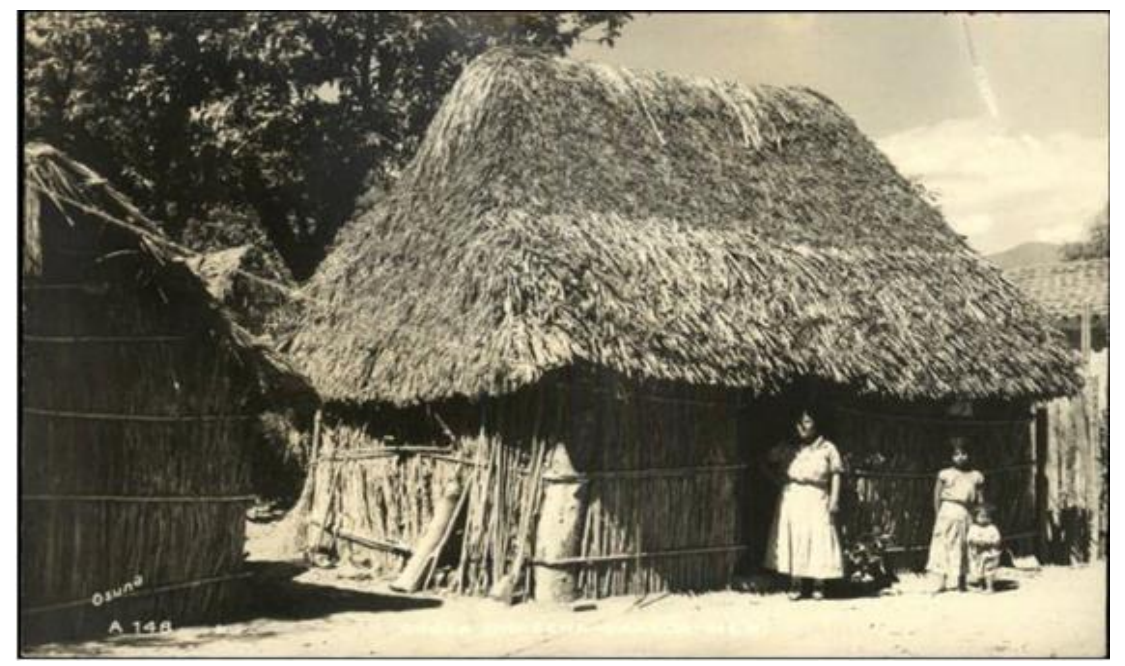

Ilustración 10. Casas de los campos. Cañazas y techo de paja. 
Invest. pens. crit. (ISSN 1812-3864)

Vol. 7, No. 1, enero- abril 2019

pp. $52-85$

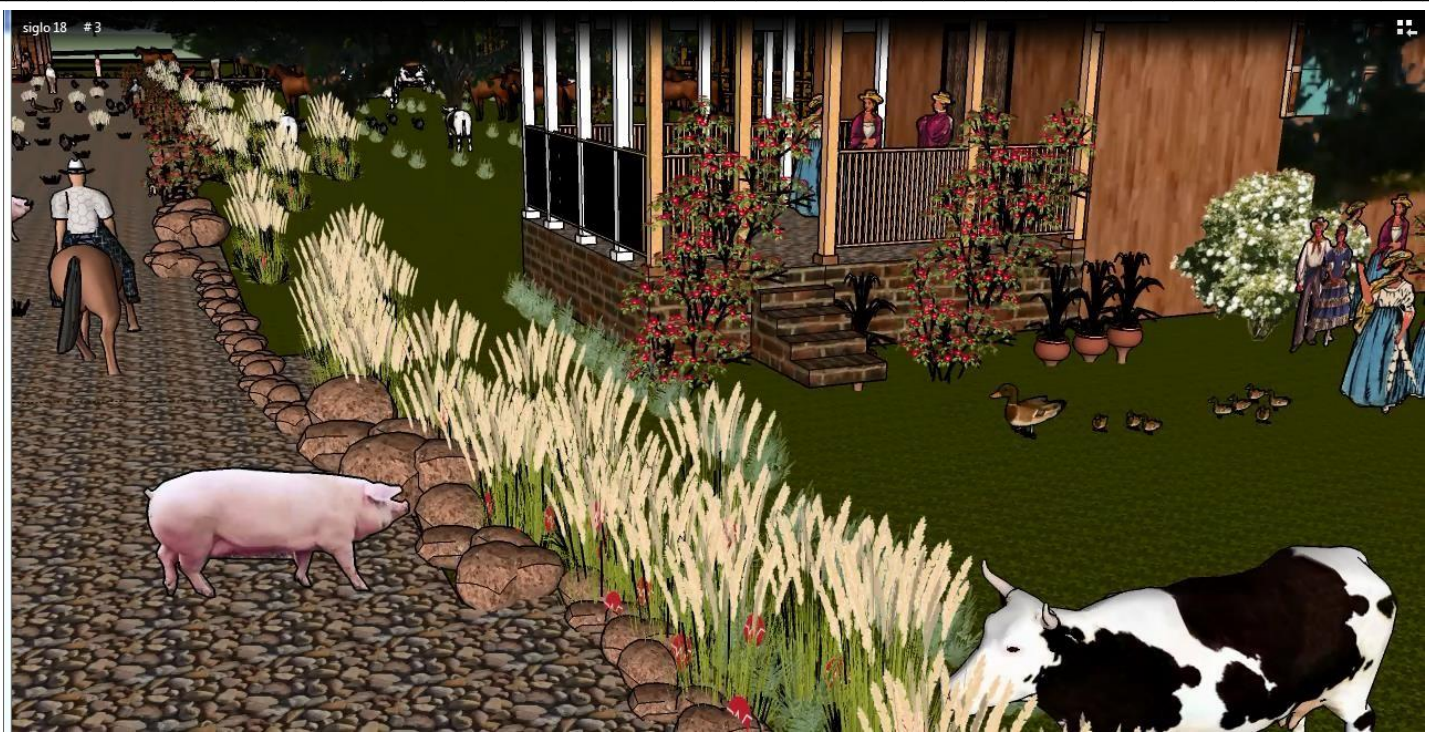

Ilustración 11. Recreación de casa de ladrillo de Santiago Siglo XVIII. Arq. Sebastián Aguilar, dibujo Freddy Ortega.

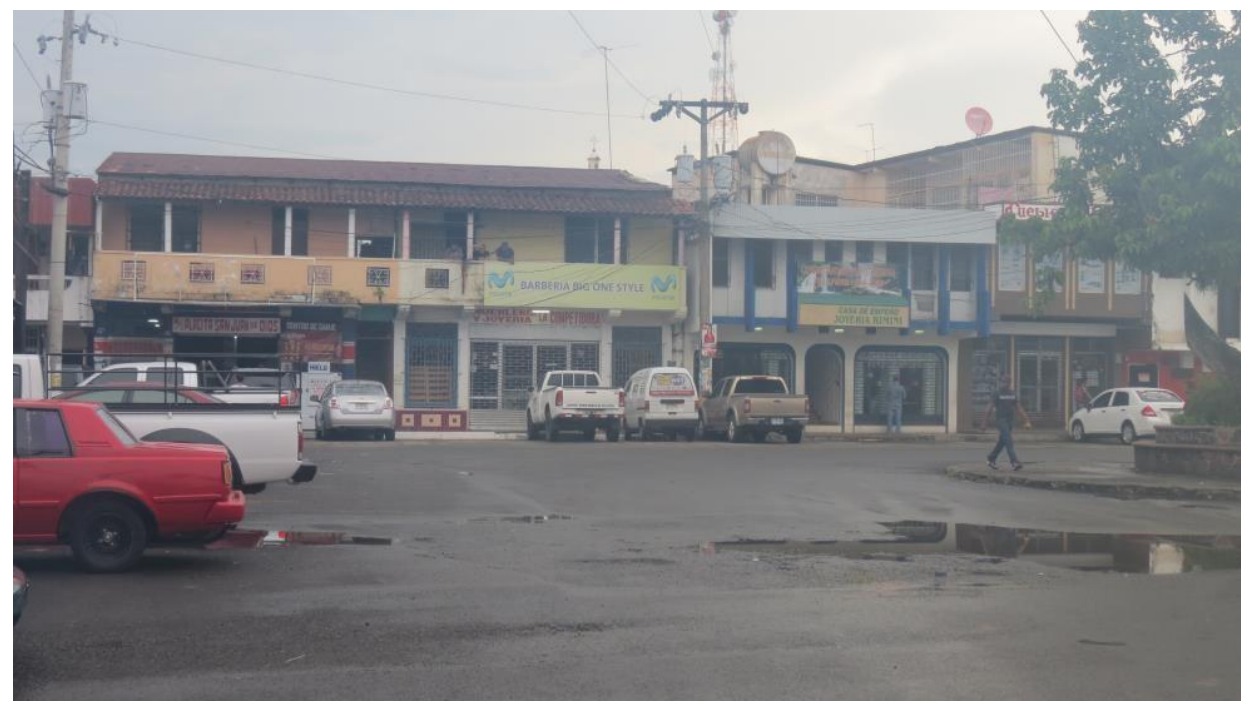

Ilustración 12. Actual Placita San Juan de Dios creada en el Siglo XVIII. Foto Arq. Sebastián Aguilar. 


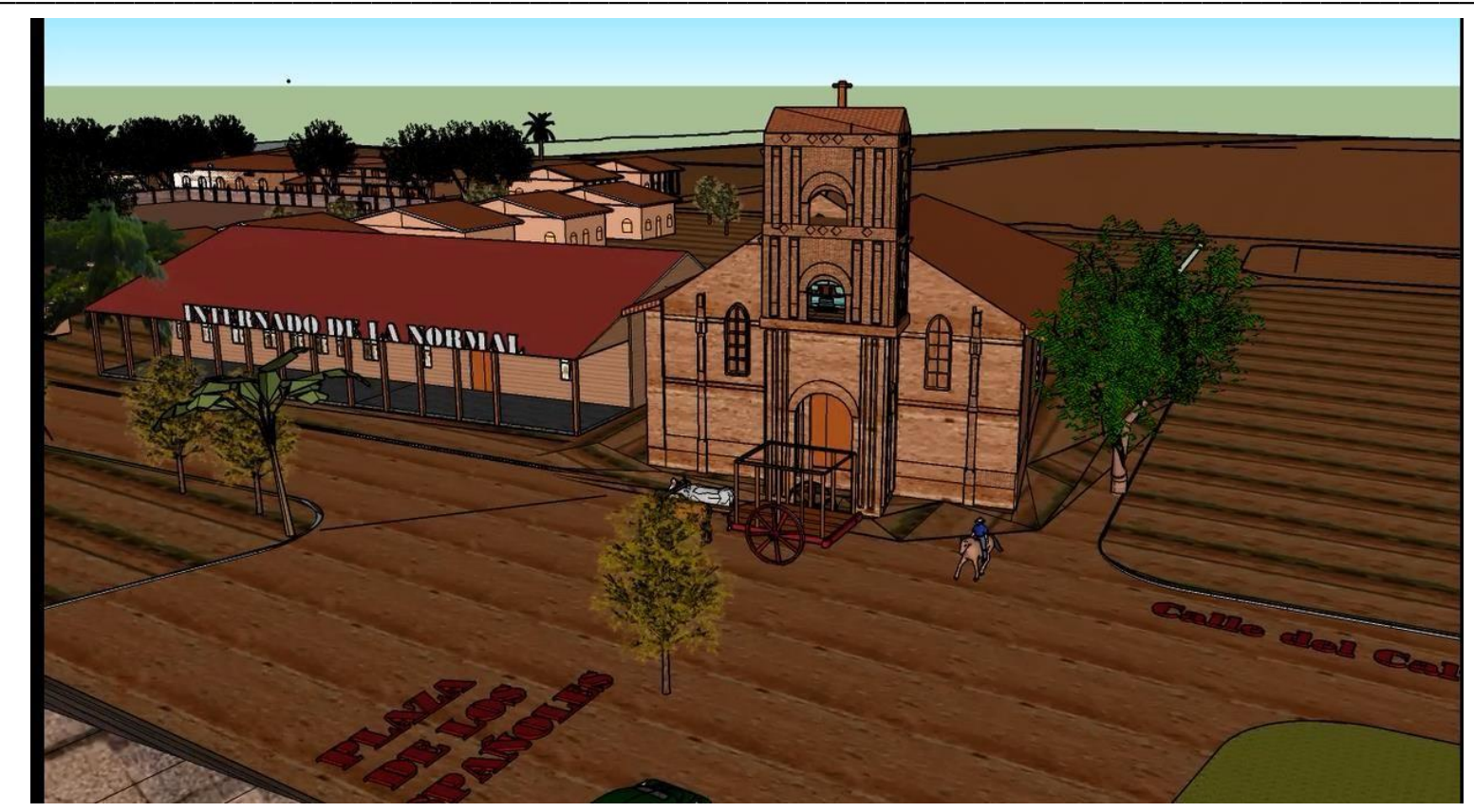

Ilustración 13. Recreación posible de la Plaza de los Españoles o Placita San Juan de Dios, en el Siglo XVIII. Santiago de Veraguas, Arq. Sebastián Aguilar, dibujo Freddy Ortega.

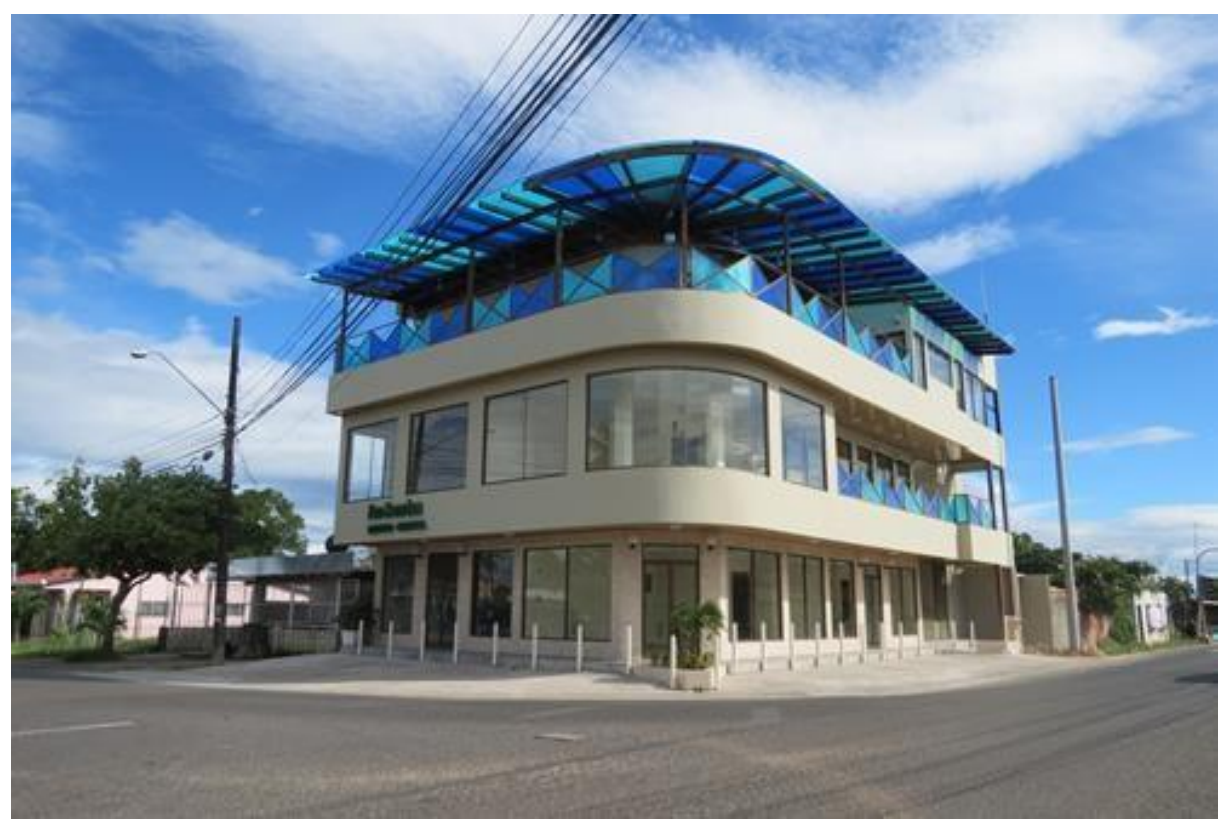

Ilustración 14. Vista actual de la posición que ocupaba la antigua Plazoleta de San Antonio, barrio de artesanos, afros y mestizos de la ciudad de Santiago Siglo XVIII. Foto Arq. Sebastián Aguilar. 
Invest. pens. crit. (ISSN 1812-3864)

Vol. 7, No. 1, enero- abril 2019

pp. $52-85$

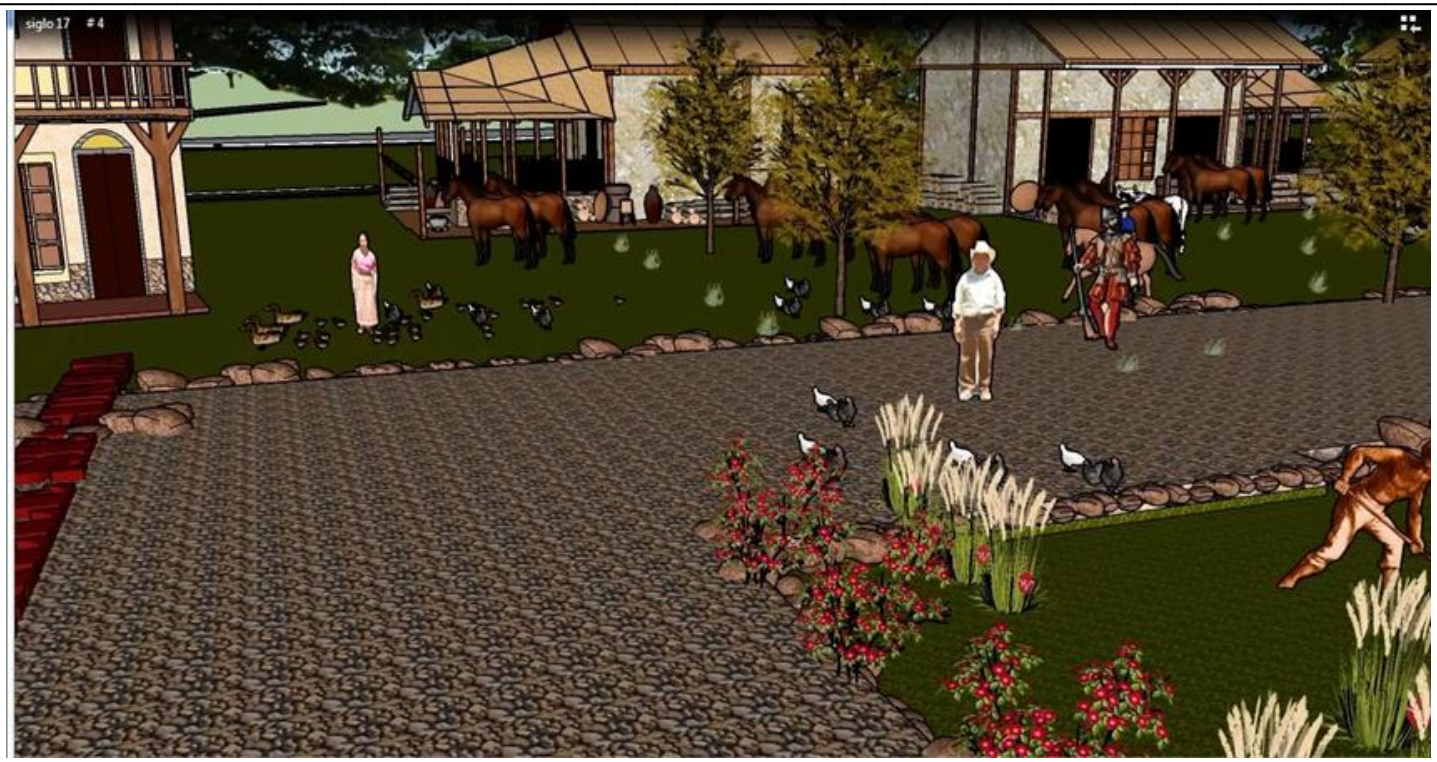

Ilustración 15. Recreación de casas en Calle Real, actual Calle Segunda, Siglo XVIII, Santiago. Arquitecto Sebastián Aguilar dibujo Fredy Ortega.

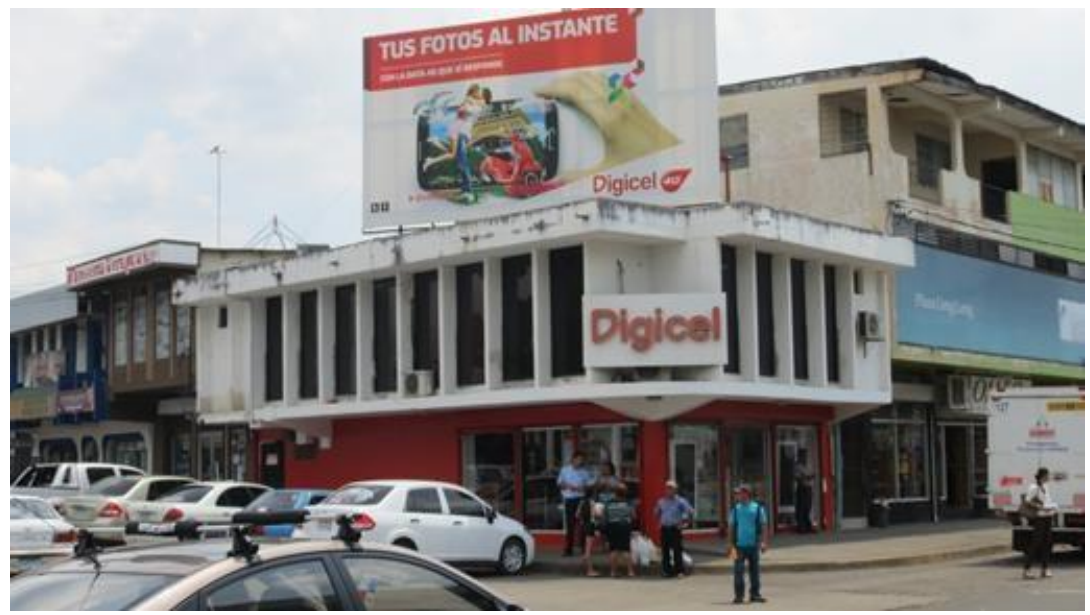

Ilustración 16. Posición actual donde quedaba la Casa de Gobernadores. Finales de Siglo XVIII. Foto Arq. Sebastián Aguilar 


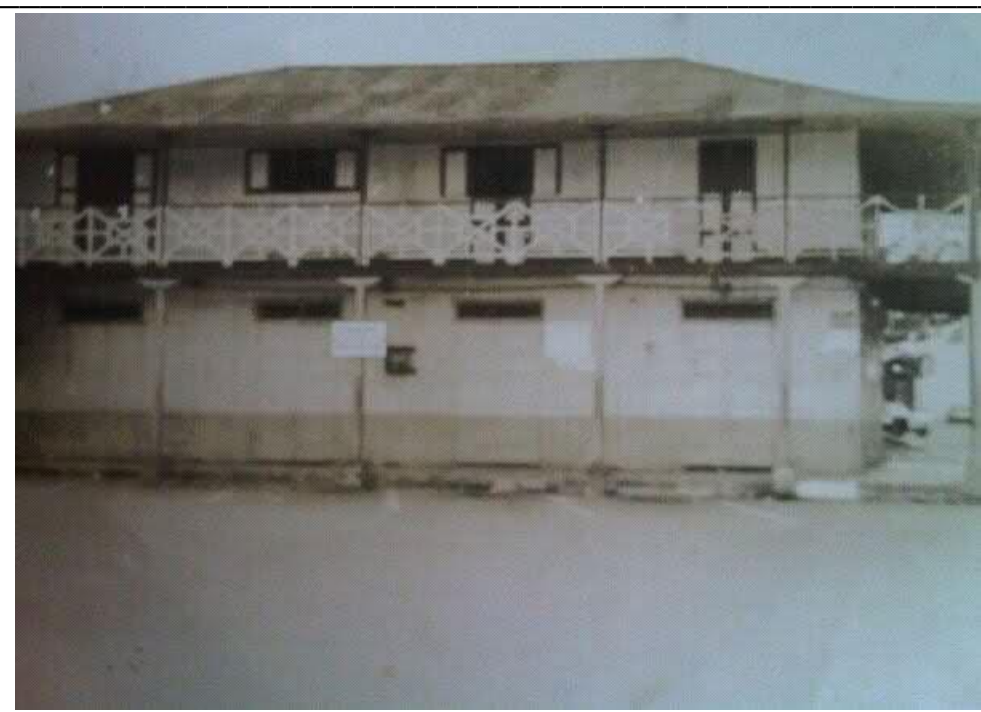

Ilustración 17. En esta posición también estuvo ubicada la antigua residencia de la Familia Sanson a inicio de Siglo XX. Foto Anónima.

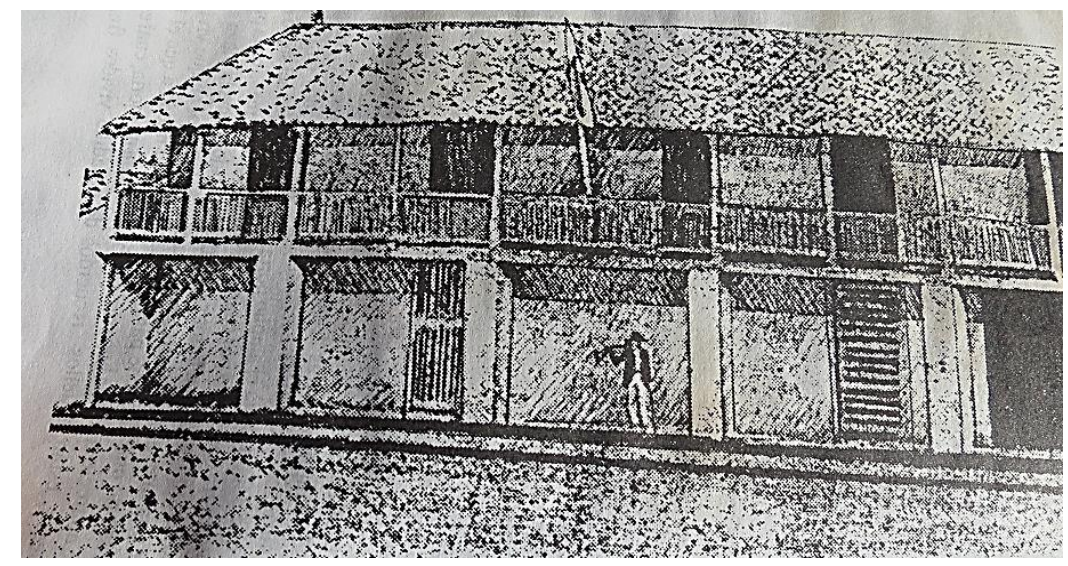

Ilustración 18. Dibujo de finales del Siglo XIX de la Casa Capitular y Cárcel construida en 1759. Dibujo del libro de Reginaldo Macías. Recuerdos de mi Santiago Natal. 
Invest. pens. crit. (ISSN 1812-3864)

Vol. 7, No. 1, enero- abril 2019

pp. $52-85$

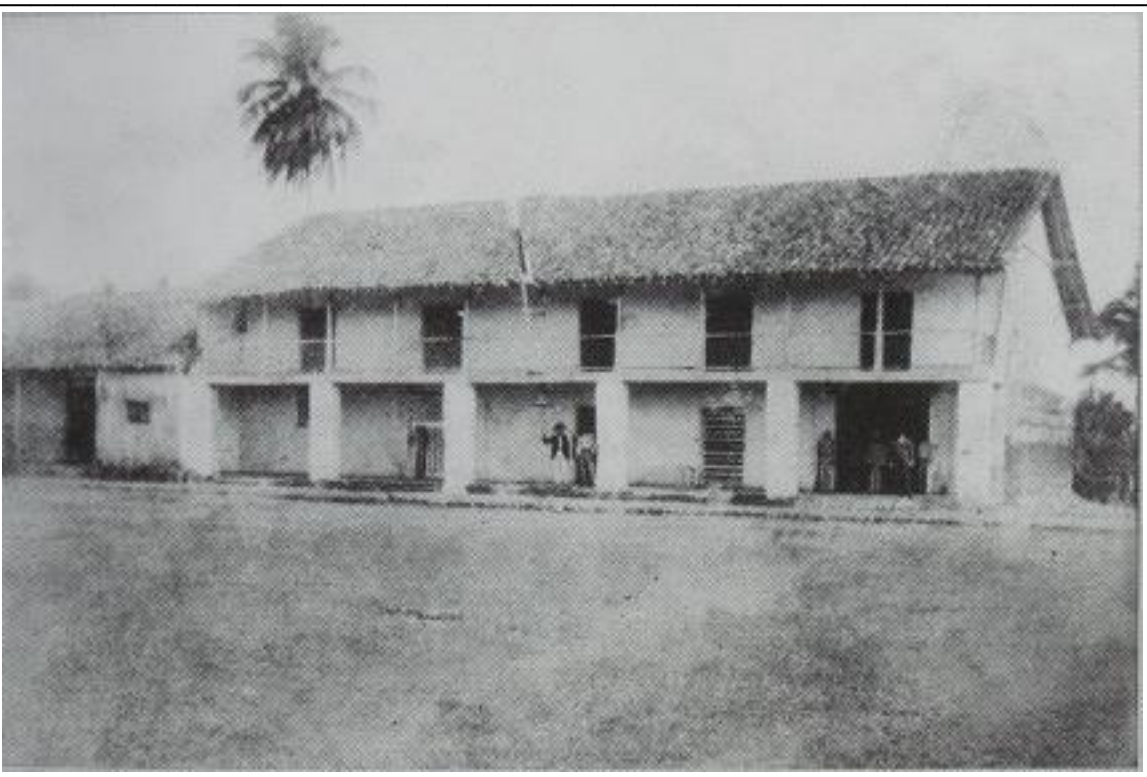

Ilustración 19. Foto de la Casa Capitular y cárcel de Santiago de Veraguas finales de Siglo XIX. Tomado del libro de Reginaldo Macías, Recuerdos de mi Santiago Natal.

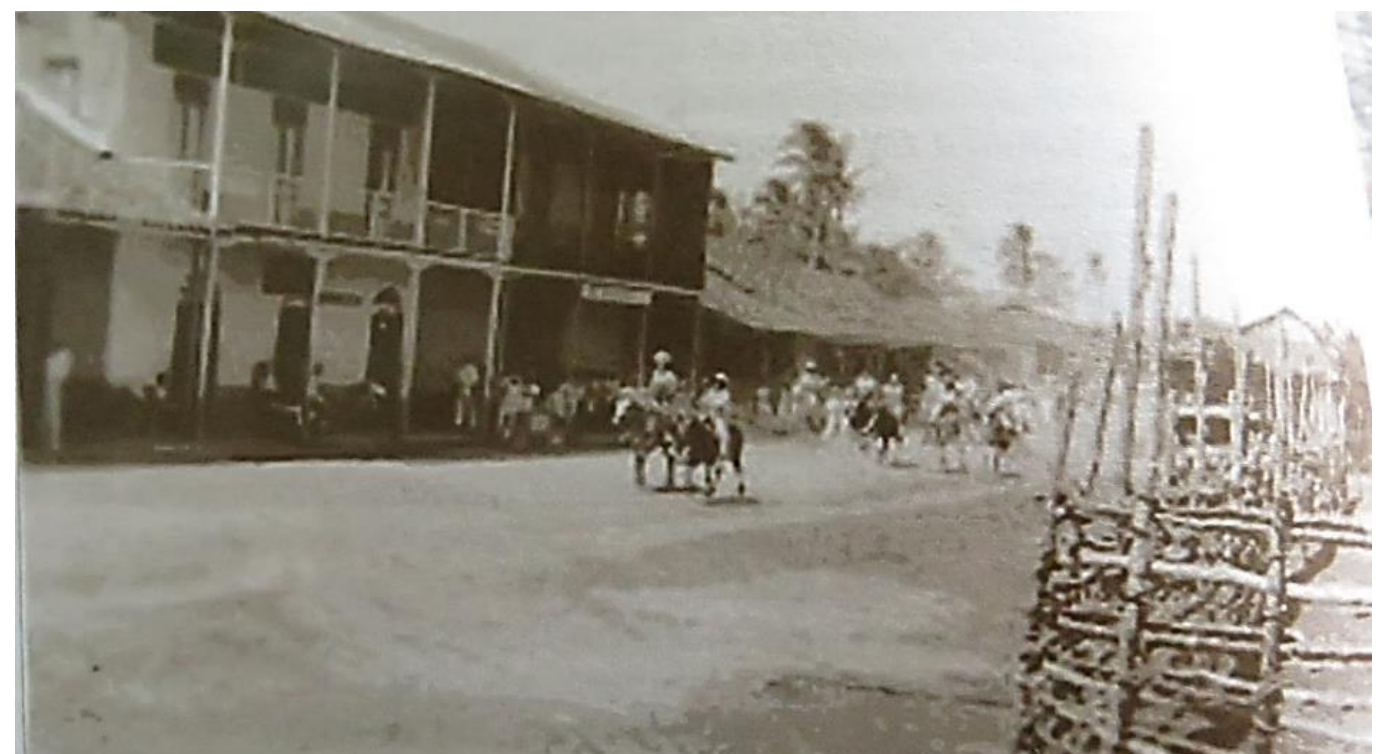

Ilustración 20. Foto de la Casa Capitular de Santiago de Veraguas inicios de Siglo XX. Foto tomada del libro de Mario Molina, Veragua: Tierra de Colón y Urracá. 


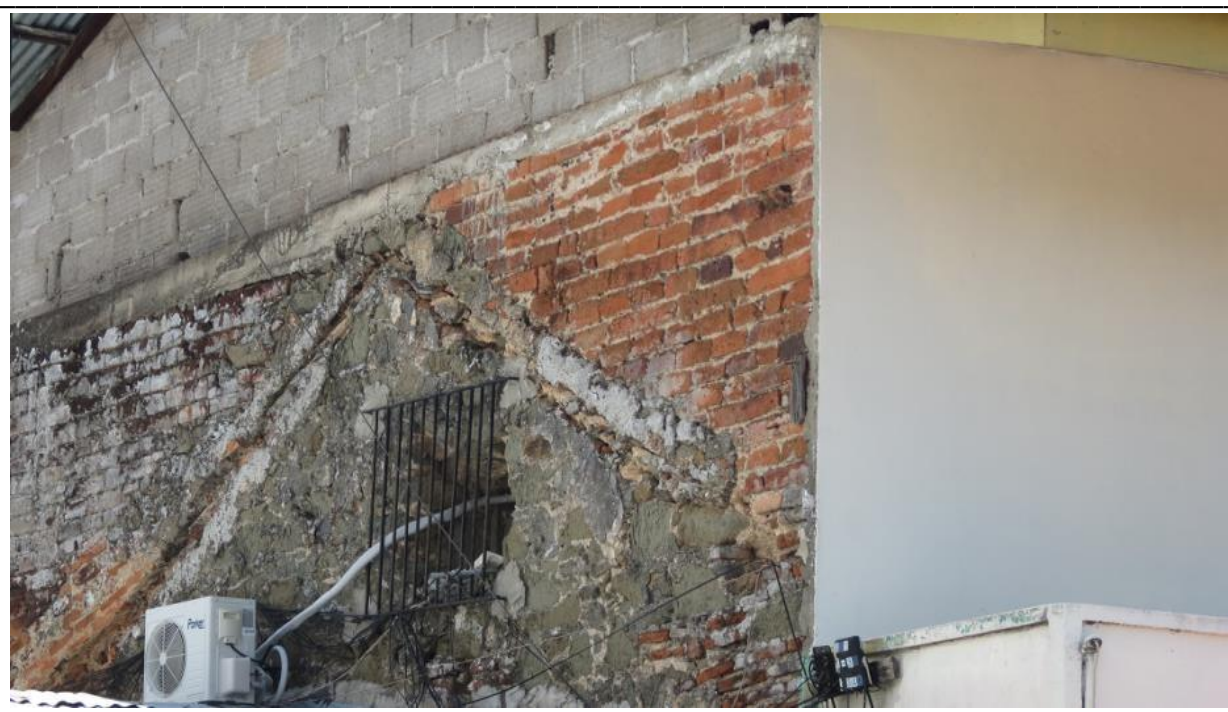

Ilustración 21. Foto de Pared actual del Palacio Municipal antigua Casa Capitular y Cárcel de Santiago donde se aprecia el material original en piedra y ladrillo con que fue construido. Foto Arq. Sebastián Aguilar.

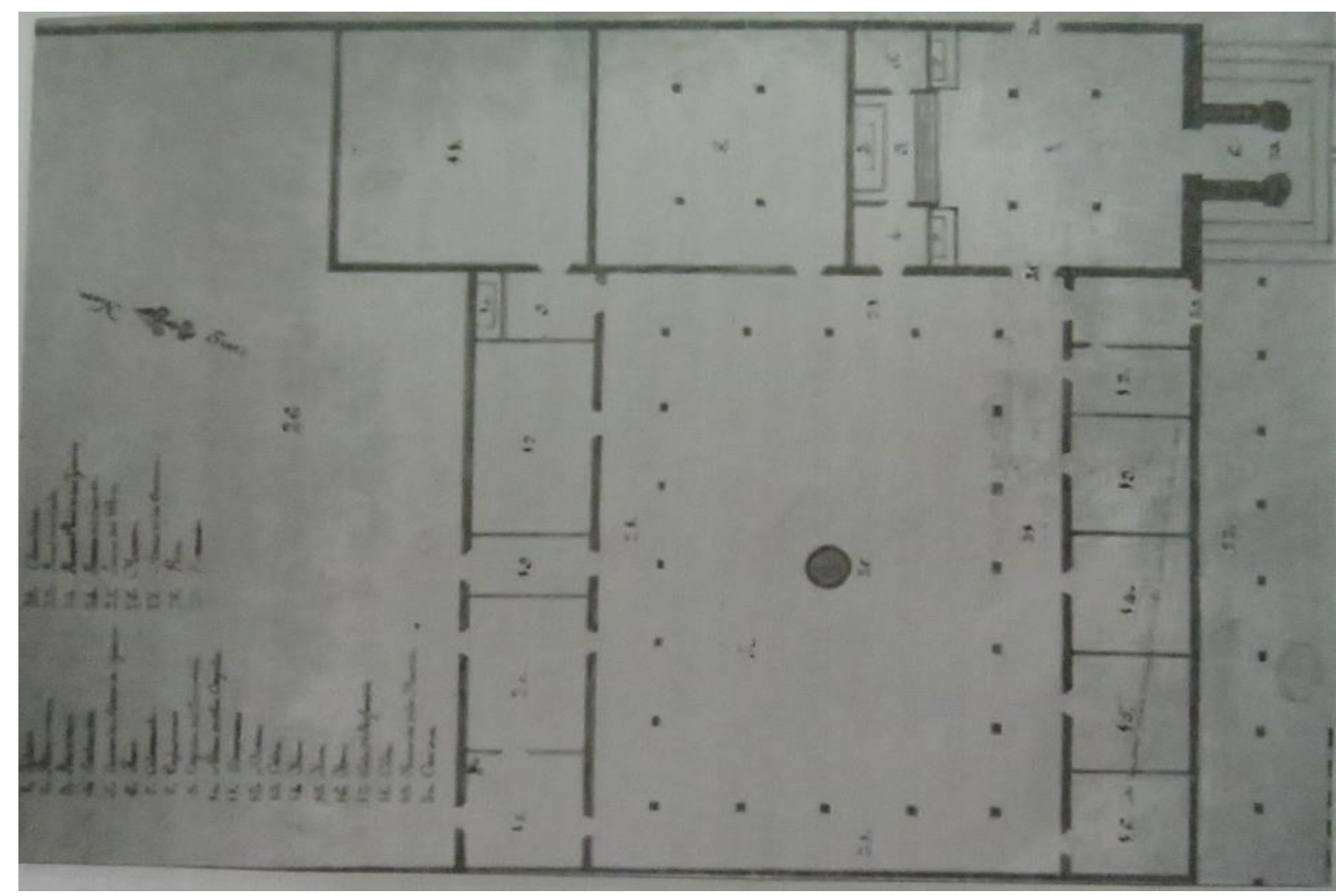

Ilustración 22. Plano del Hospital San Juan De Dios y la Iglesia San Juan de Dios o Santa Bárbara, inaugurados en 1770.

Por primera vez se utiliza una planta arquitectónica para construir un proyecto en la ciudad de Santiago de Veragua. Siglo XVIII. Tomado del libro de Mario Molina, Veragua Tierra de Colón y Urracá. 
Invest. pens. crit. (ISSN 1812-3864)

Vol. 7, No. 1, enero- abril 2019

pp. $52-85$

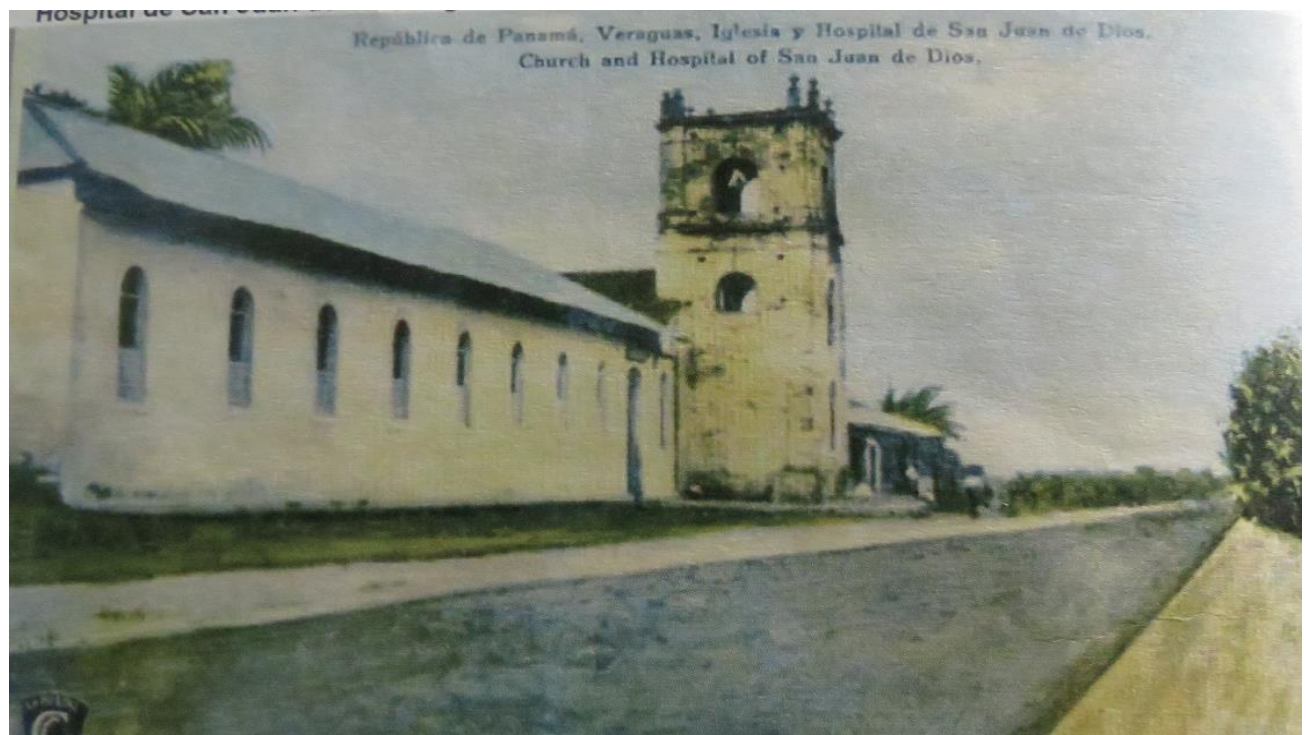

Ilustración 23. Dibujo de Hospital San Juan de Dios y la Iglesia Santa Bárbara. Foto tomada del libro de Mario Molina, Veragua: Tierra de Colón y Urracá.

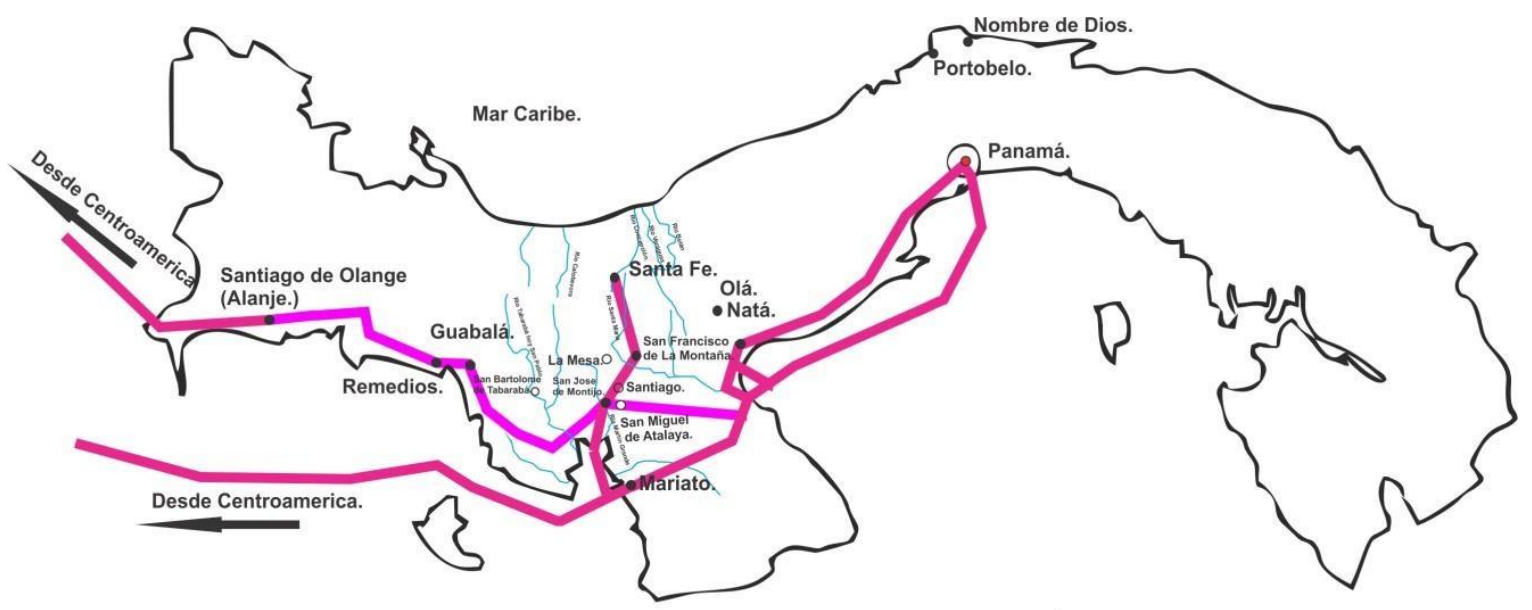

Mapa sobre rutas terrestres y marítimas de Veraguas en la Época Colonial.

Siglo XVII.

Ilustración 24. Rutas terrestres y marítimas de Veragua Siglo XVII. Dibujo Arq.

Sebastián Aguilar. 


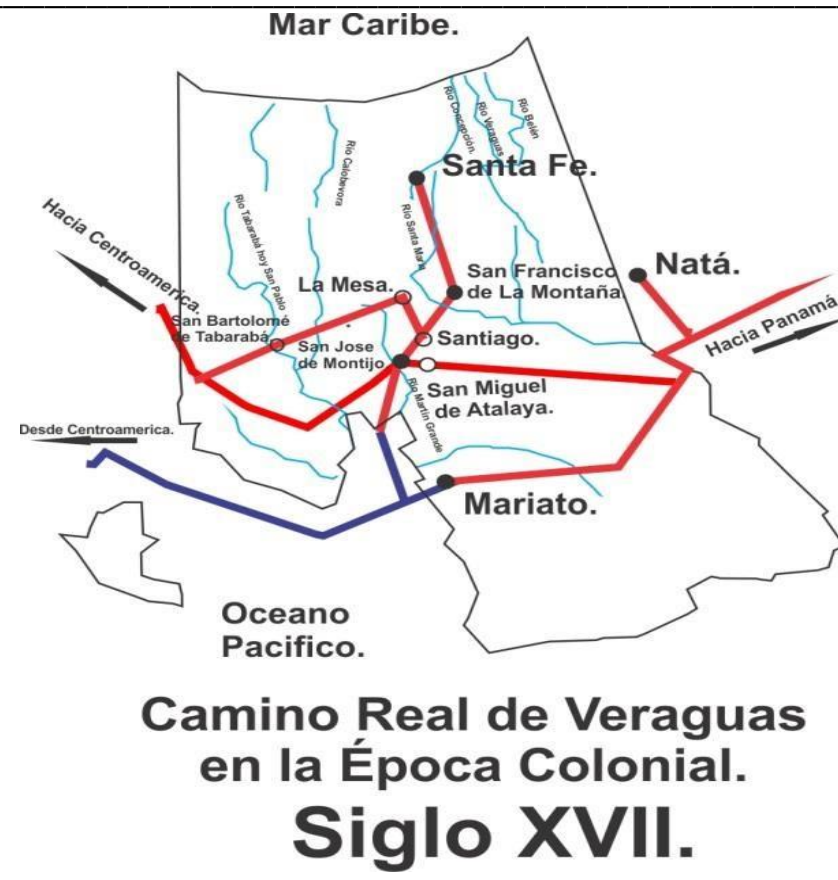

Ilustración 25. Camino Real de Veraguas Epoca Colonia. Dibujo Arq. Sebastián Aguilar.

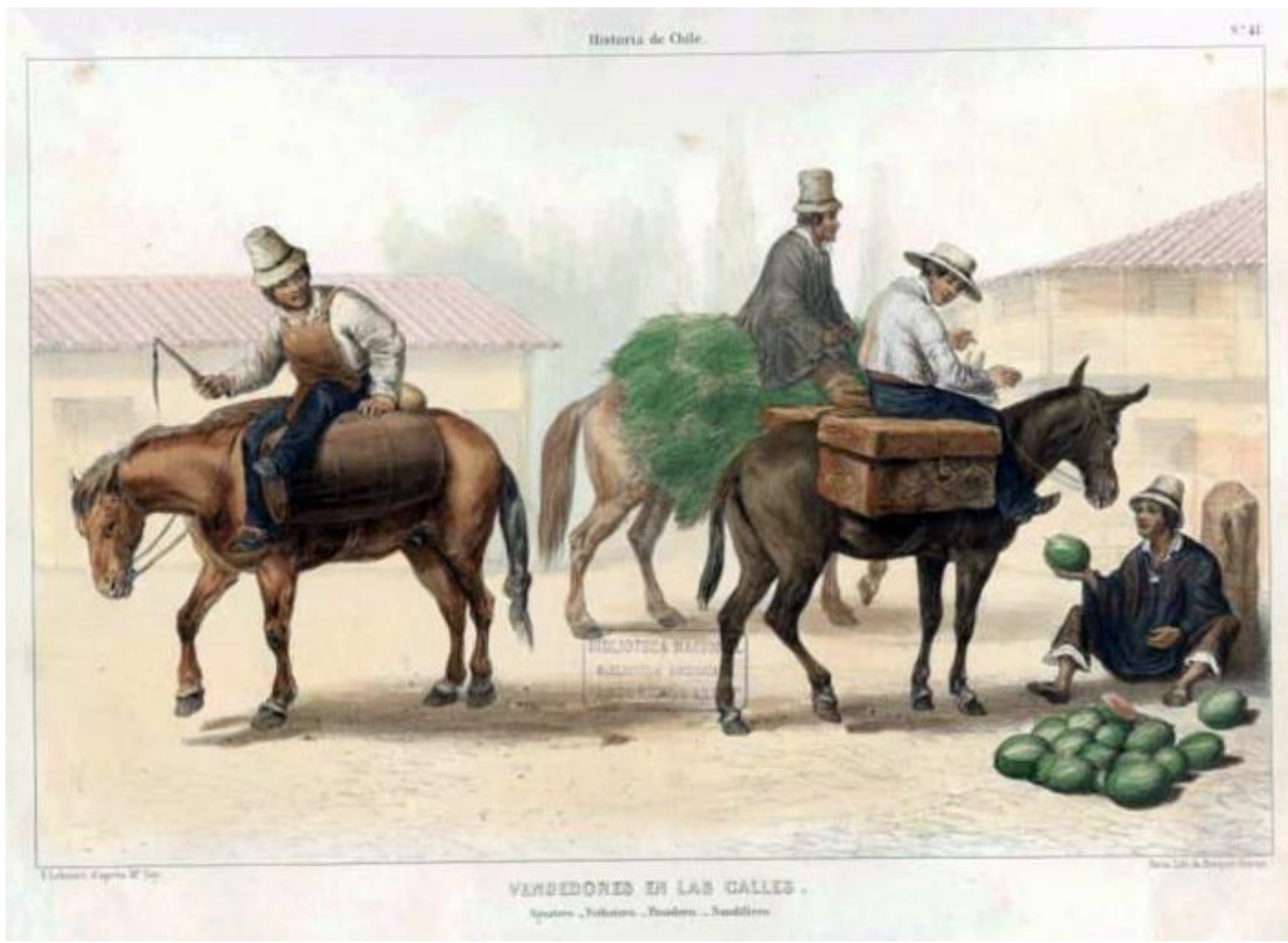

Ilustración 26. Transporte en la época Colonial. 
Invest. pens. crit. (ISSN 1812-3864)

Vol. 7, No. 1, enero- abril 2019

pp. $52-85$

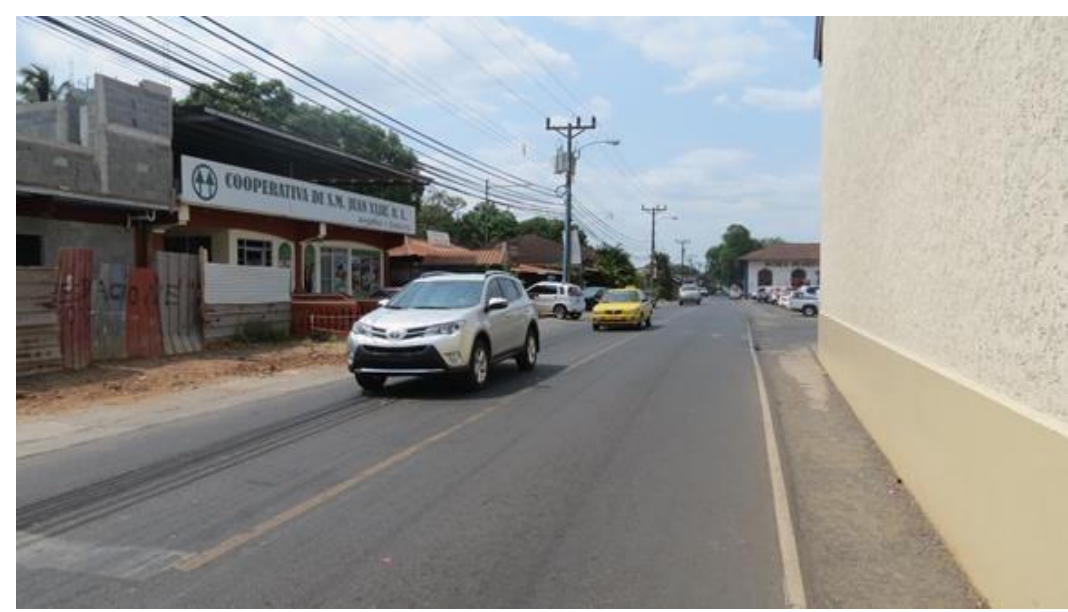

Ilustración 27. Actual Calle segunda antigua Calle Real. Foto Arq. Sebastián Aguilar.

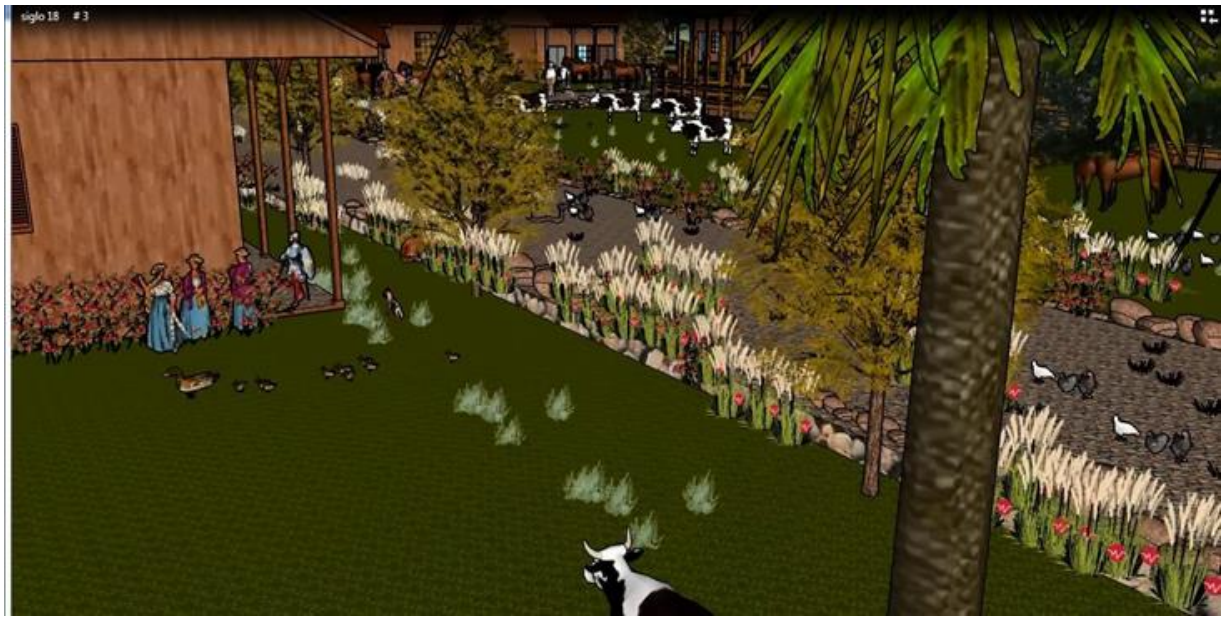

Ilustración 28. Posible recreación de la Calle Real, actual Calle Segunda, en el Siglo XVIII. Arq. Sebastián Aguilar dibujo Fredy Ortega. 


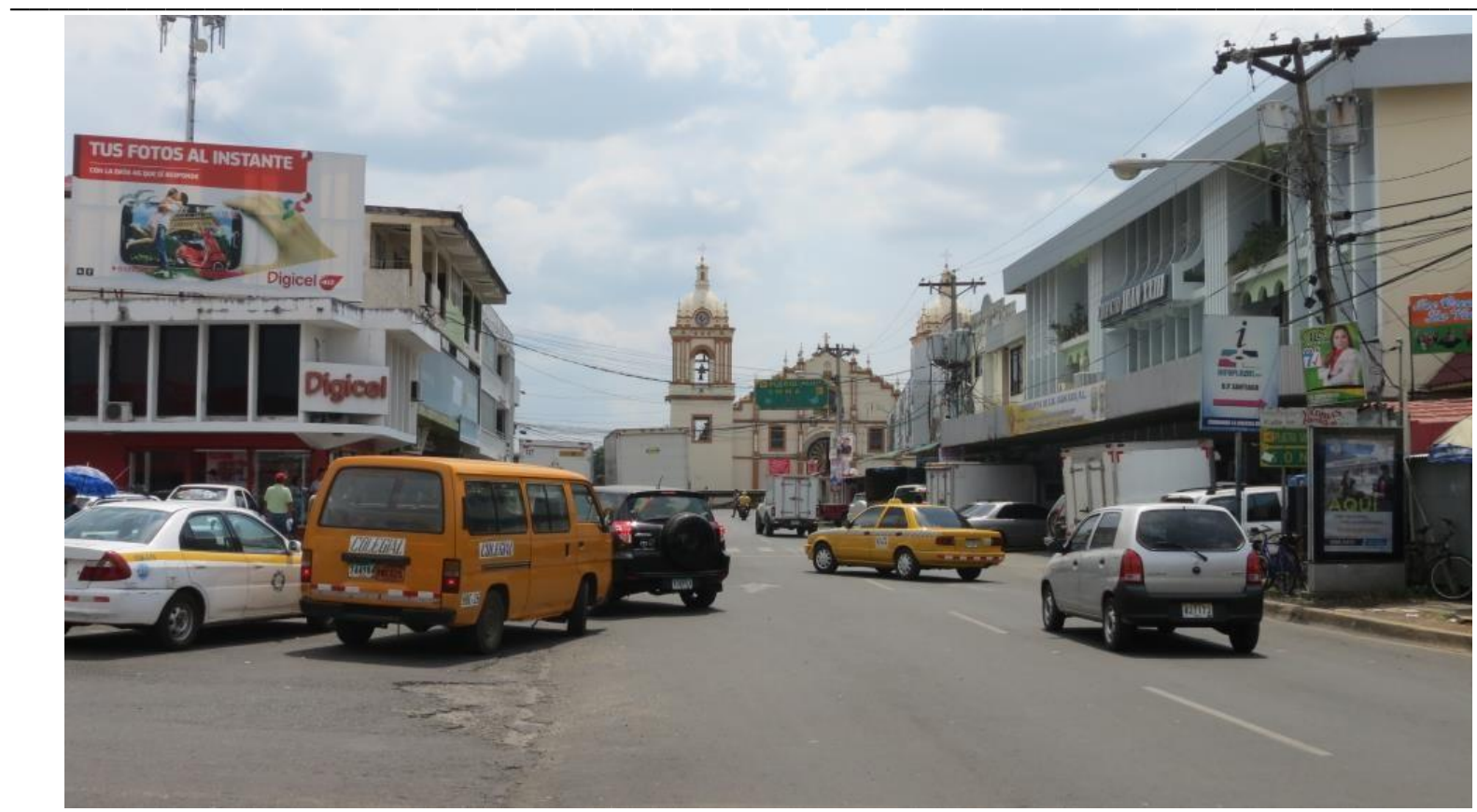

Ilustración 29. Actual Avenida Central, antigua Calle del Calvario. Siglo XVI al XX. Foto Arq. Sebastián Aguilar.

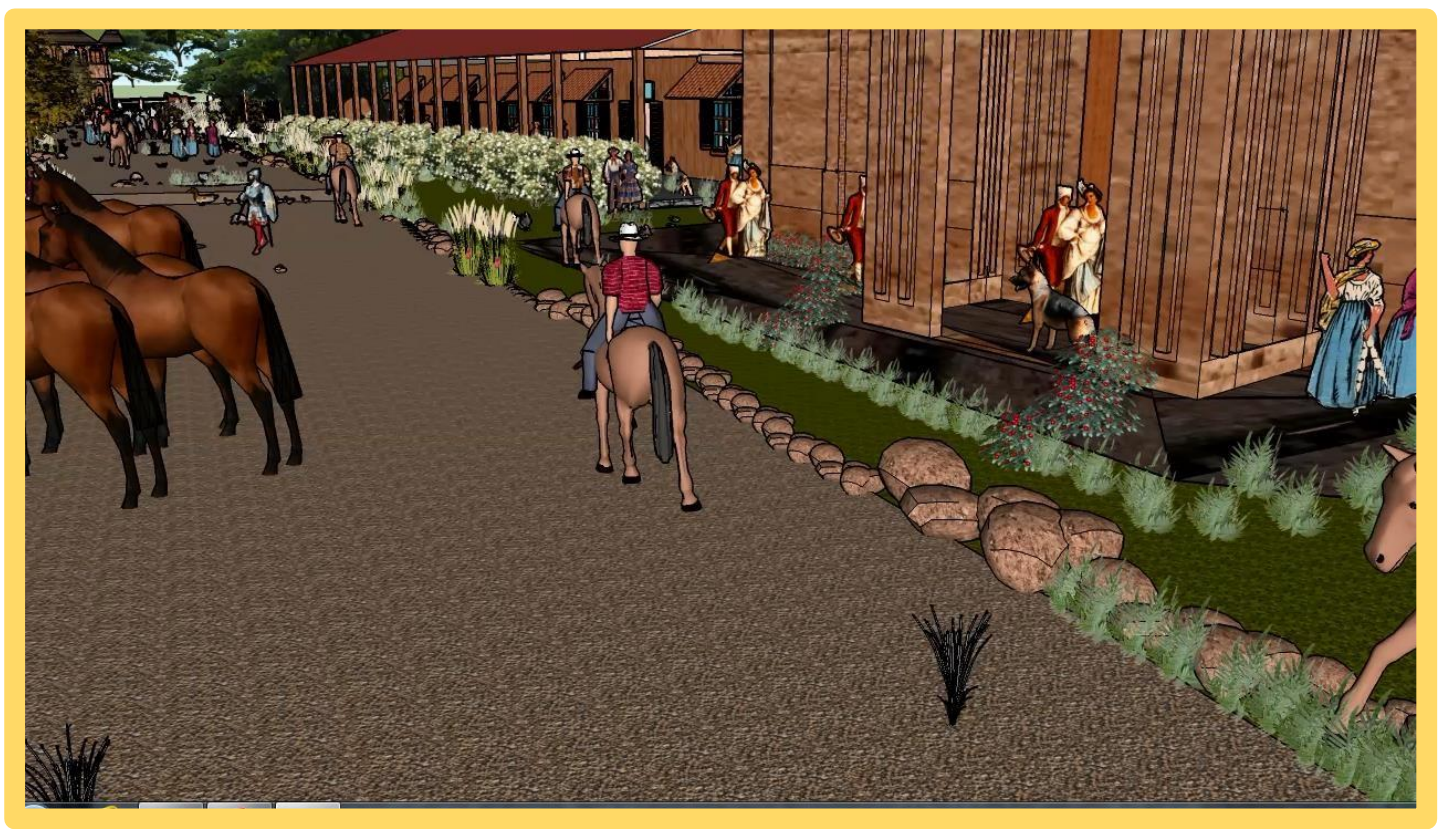

Ilustración 30. Recreación de la Calle del Calvario actual Avenida Central. Arq. Sebastián Aguilar Dibujo Freddy Ortega. 
Invest. pens. crit. (ISSN 1812-3864)

Vol. 7, No. 1, enero- abril 2019

pp. $52-85$

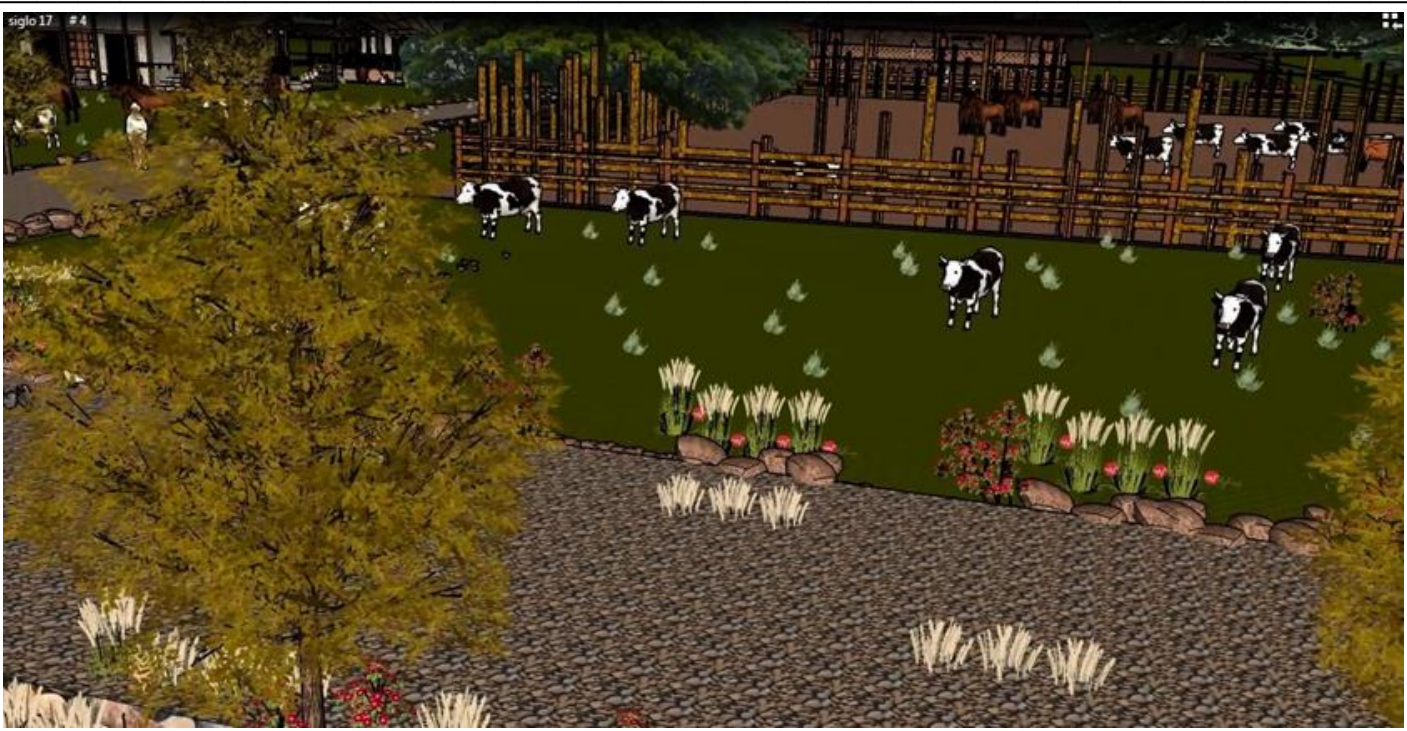

Ilustración 31. Recreación de Plaza Mayor en temporada de rodeo, con cerca de maderas o ramas. Arq. Sebastián Aguilar dibujo Fredy Ortega.

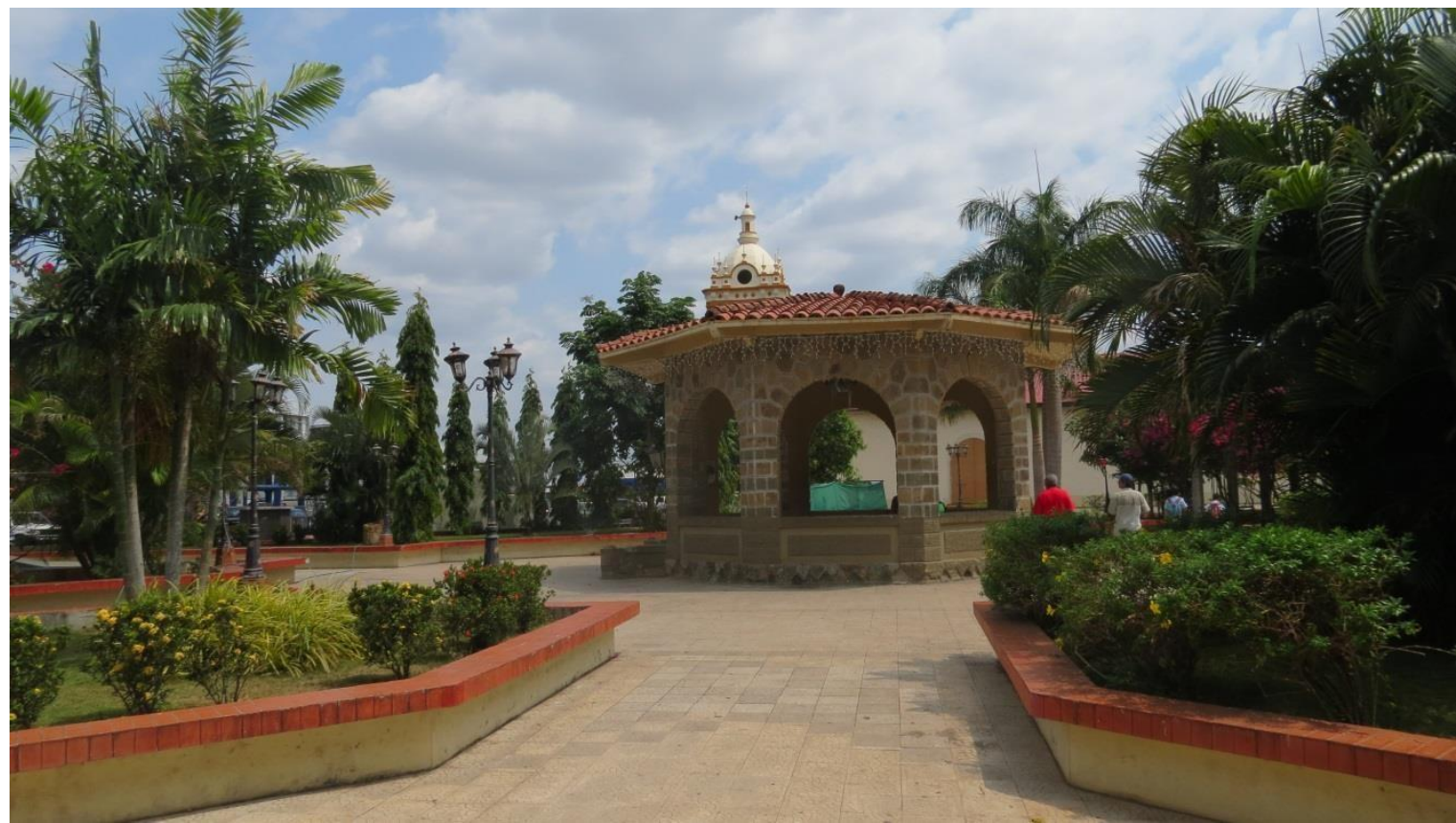

Ilustración 32. Foto actual del Parque Juan Demóstenes Arosemena, antigua Plaza Mayor. Foto Arq. Sebastián Aguilar 


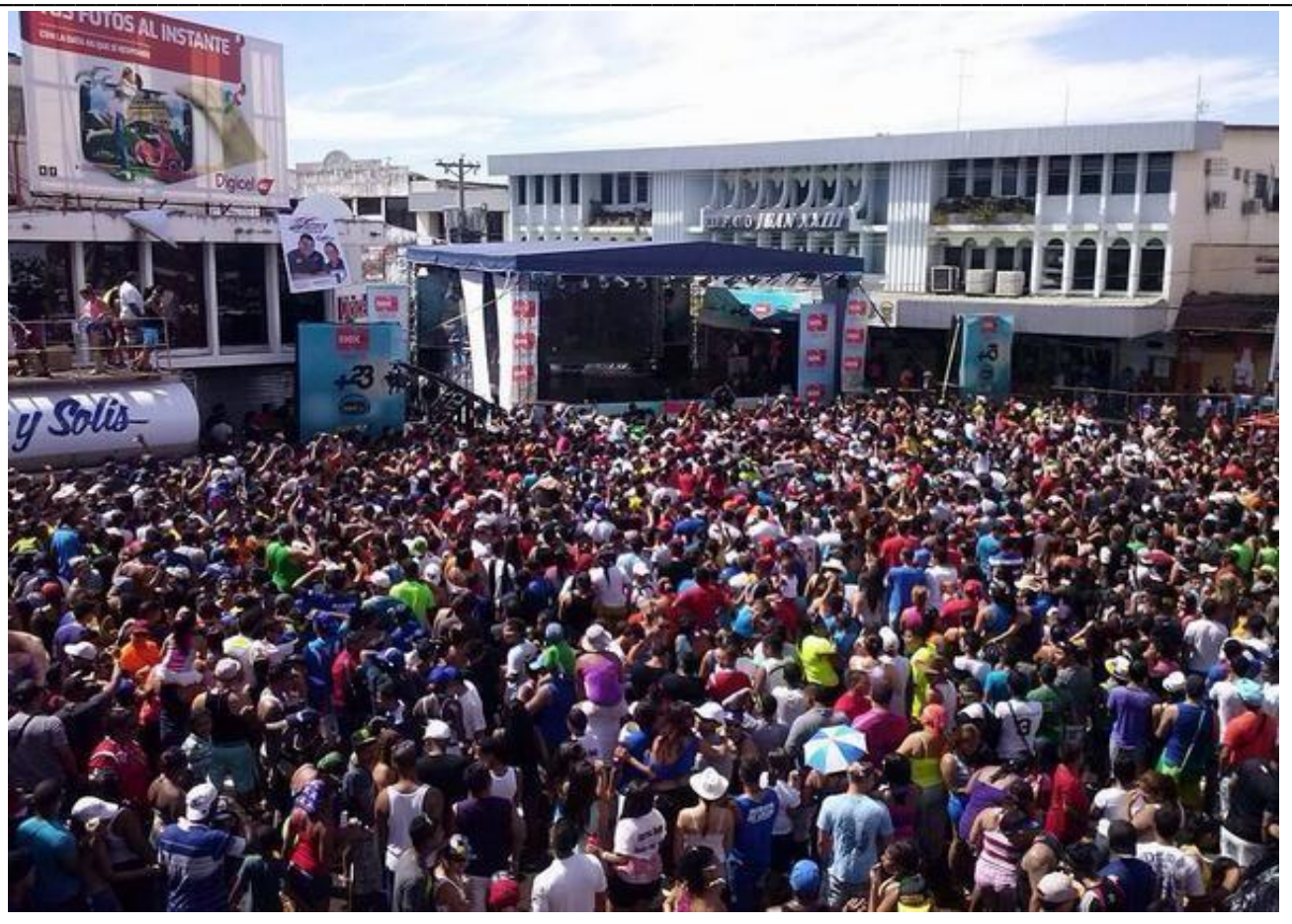

Ilustración 33. Foto de la Actual Plaza San Juan de Dios creada en el Siglo XVIII. Foto Arq. Sebastián Aguilar.

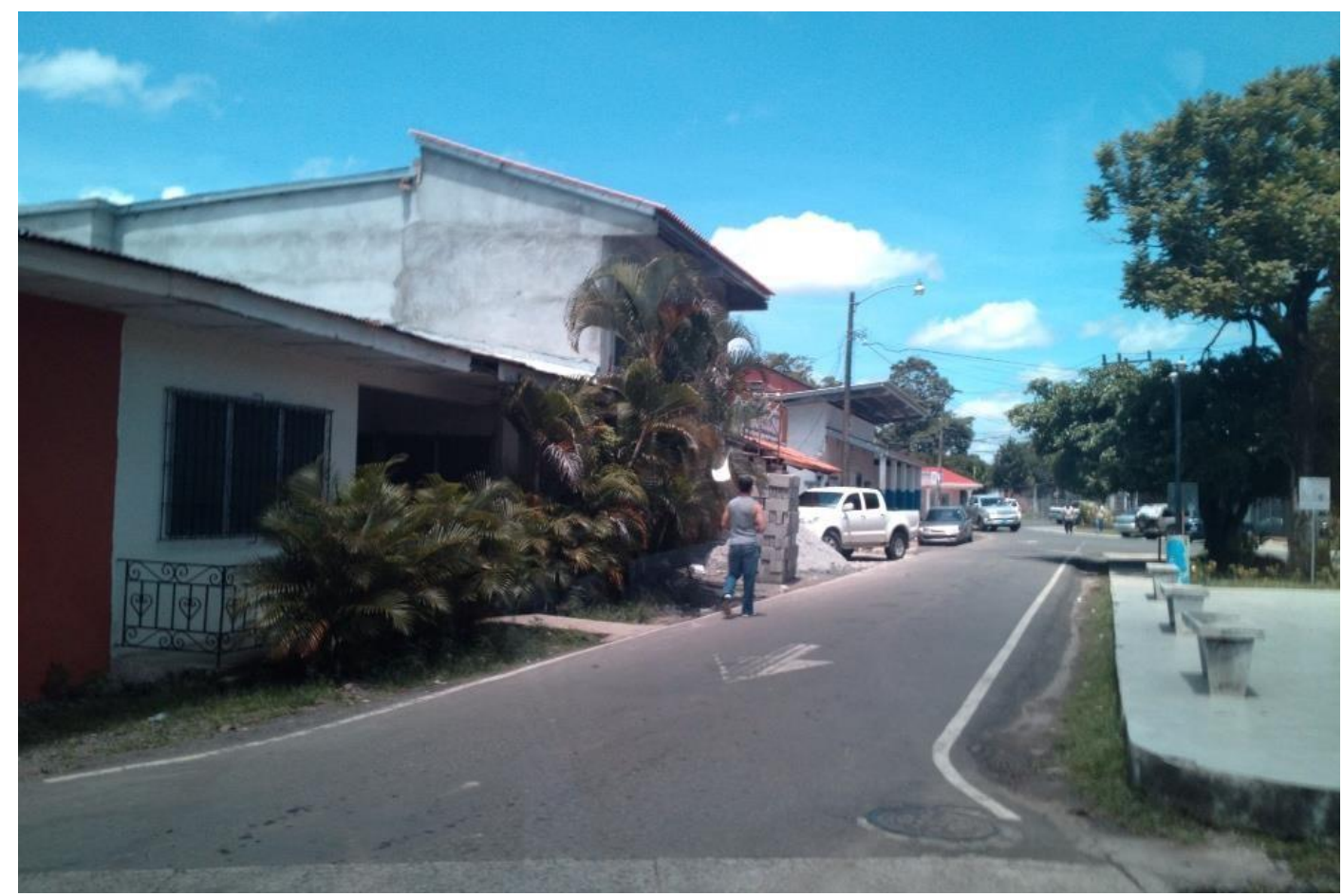

Ilustración 34. Cerca del actual Parque de la Amistad fue el área conocida como Plazoleta de San Antonio, desde el Siglo XVIII, en la ciudad de Santiago de Veraguas. Foto Arq. Sebastián Aguilar. 
Invest. pens. crit. (ISSN 1812-3864)

Vol. 7, No. 1, enero- abril 2019

pp. $52-85$

\section{Tablas.}

\section{Cuadros}

Cuadro 1. Teorías sobre fundación de la Ciudad de Santiago de Veraguas.

\begin{tabular}{|c|c|c|c|c|}
\hline Año & teoría & documento & lugar & Citada \\
\hline 1518 & $\begin{array}{l}\text { fundada por Diego de } \\
\text { Alvítez y Gaspar de } \\
\text { Espinoza }\end{array}$ & $\begin{array}{l}\text { basados en cfc. } \\
\text { Antonio } \\
\text { Documentos } \\
\text { inéditos. Vol. 11, pág. } \\
342\end{array}$ & $\begin{array}{l}\text { en las grandes } \\
\text { sabanas a orillas } \\
\text { del Rio Martin } \\
\text { Grande cerca del } \\
\text { balneario } \\
\text { "Los Chorros" }\end{array}$ & $\begin{array}{l}\text { - (Botello Pino, } \\
\text { Esilda. 1995) } \\
\text {-Reverendo Vidal } \\
\text { Fernández de } \\
\text { Palomares (1904 - } \\
\text { 1997) } \\
\text {-Hermanos } \\
\text { Antonio de Ulloa y } \\
\text { Jorge Juan de Ulloa } \\
\text { 1736. } \\
\text {-relatos } \\
\text { tradicionales de } \\
\text { Don Luis E. de } \\
\text { Fábrega. } \\
\text {-Berthold Seeman } \\
\text { Historia General } \\
\text { de Panamá Siglo } \\
\text { XIX). }\end{array}$ \\
\hline 1560 & Santiago Doctrinera & $\begin{array}{ll}\text { mencionada } & \text { por el } \\
\text { historiador } & \text { Rubén } \\
\text { Darío Carles } & \end{array}$ & & $\begin{array}{l}\text { (Botello Pino, } \\
\text { Esilda. } \\
\text { 1995) }\end{array}$ \\
\hline 1573 & $\begin{array}{l}\text { Santiago como } \\
\text { encomienda doctrinera. } \\
\text { "Los Llanos de } \\
\text { Santiago" }\end{array}$ & $\begin{array}{l}\text { "Conquista, } \\
\text { Evangelización } \\
\text { y Resistencia" } \\
\text { de Alfredo Castillero } \\
\text { Calvo. }\end{array}$ & $\begin{array}{l}\text { las cercanías del } \\
\text { Río Los Chorros }\end{array}$ & $\begin{array}{lr}\text { Gaspar } & \text { Rosas } \\
\text { Quirós. } & \text { Botello } \\
\text { Pino, Esilda. } & \\
1995) & \end{array}$ \\
\hline 1607 & $\begin{array}{l}\text { "Jurisdicción } \\
\text { Santiago" }\end{array}$ & $\begin{array}{l}\text { El Archivo General de } \\
\text { Indias, en } 1607\end{array}$ & & $\begin{array}{l}\text { del Dr. Omar Jaén } \\
\text { Suarez. (1999) }\end{array}$ \\
\hline 1607 & "El pueblo del Río Martín" & $\begin{array}{l}\text { informe de Obispo } \\
\text { Antonio Calderón }\end{array}$ & $\begin{array}{l}\text { "Elpueblo del Río } \\
\text { Martín" }\end{array}$ & $\begin{array}{l}\text { Molina Castillo, } \\
\text { Mario José. 2013) }\end{array}$ \\
\hline 1609 & $\begin{array}{l}\text { Legalidad de la creación } \\
\text { de Santiago de Veragua. }\end{array}$ & $\begin{array}{l}\text { Cedula fechada en } \\
\text { Madrid el } 19 \text { de enero } \\
\text { de } 1609 \text { La Corona } \\
\text { aceptaba la solicitud } \\
\text { de la Audiencia. la } \\
\text { unificación de } \\
\text { Montijo y Santa Fe. }\end{array}$ & & $\begin{array}{l}\text { (Molina Castillo, } \\
\text { Mario José. 2013) }\end{array}$ \\
\hline
\end{tabular}


Invest. pens. crit. (ISSN 1812-3864)

Vol. 7, No. 1, enero- abril 2019

pp. $52-85$

\begin{tabular}{|c|c|c|c|}
\hline 1614 & $\begin{array}{l}\text { primera ciudad. } \\
\text { parroquia Doctrinera }\end{array}$ & $\begin{array}{l}\text { "Síntesis Histórica de } \\
\text { Santiago de Veraguas" } \\
\text { Informe Esilda } \\
\text { Botello } \\
\text { Pino }\end{array}$ & $\begin{array}{l}\text { Nicolás Caballero } \\
\text { Esilda Botello Pino }\end{array}$ \\
\hline $\begin{array}{l}1620- \\
1621\end{array}$ & $\begin{array}{l}\text { Parroquia Doctrinera. } \\
\text { fundación en } 1621 \text { el } 23 \\
\text { de octubre. } \\
\text { (Santiago de Veragua la } \\
\text { Vieja), } \\
\end{array}$ & 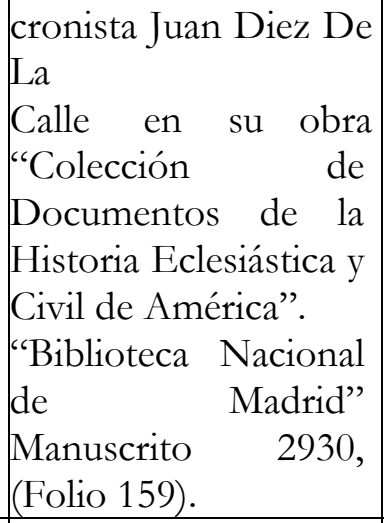 & $\begin{array}{l}\text { Alfredo } \\
\text { Calvo. }\end{array}$ \\
\hline 1635 & & "Coclé de Natá" & $\begin{array}{ll}\text { Gaspar } & \text { Rosas } \\
\text { Quiroz } & \end{array}$ \\
\hline \multirow[t]{2}{*}{1636} & $\begin{array}{l}\text { Traslado de la ciudad } \\
\text { (Santiago La Nueva) }\end{array}$ & $\begin{array}{l}\text { "Síntesis Histórica de } \\
\text { Santiago de } \\
\text { Veraguas", establece } \\
\text { la fundación de }\end{array}$ & $\begin{array}{l}\text { Nicolás Caballero } \\
\text { (Molina Castillo, } \\
\text { Mario José. 2013) }\end{array}$ \\
\hline & & \begin{tabular}{|lll} 
Santiago en 1636 y \\
como fundador a \\
Enrique & \\
Enríquez presidente \\
de la \\
Audiencia
\end{tabular} & $\begin{array}{l}\text { Alfredo Castillero } \\
\text { Calvo }\end{array}$ \\
\hline
\end{tabular}

Cuadro 2. Población del Casco Viejo de la Ciudad de Santiago de Veraguas.

\begin{tabular}{|l|l|l|l|}
\hline año & Población. & Denominación. & Datos Tomados de \\
\hline 1607 & 400 habitantes* & $\begin{array}{l}\text { "Jurisdicción } \\
\text { Santiago" }\end{array}$ & $\begin{array}{l}\text { (Dr. Omar Jaén Suarez, } \\
1999)\end{array}$ \\
\hline 1607 & & $\begin{array}{l}\text { "Jurisdicción de } \\
\text { Santiago" }\end{array}$ & $\begin{array}{l}\text { (Dr. Omar Jaén Suarez, } \\
1999)\end{array}$ \\
\hline 1640 & 528 babitantes* & $\begin{array}{l}\text { "Jurisdicción de } \\
\text { Santiago" }\end{array}$ & $\begin{array}{l}\text { (Dr. Omar Jaén Suarez, } \\
1999)\end{array}$ \\
\hline 1691 & 1,520 babitantes* & $\begin{array}{l}\text { (Molina Castillo, Mario } \\
\text { José. } \\
\text { 2013) }\end{array}$ \\
\hline 1691 & $\begin{array}{l}\text { Aprox. } 1000 \text { babitantes } \\
1734\end{array}$ & $\begin{array}{l}\text { (Molina Castillo, Mario } \\
\text { José. }\end{array}$ \\
\hline
\end{tabular}


Invest. pens. crit. (ISSN 1812-3864)

Vol. 7, No. 1, enero- abril 2019

pp. $52-85$

\begin{tabular}{|c|c|c|c|}
\hline & & & 2013) \\
\hline 1736 & 4,950 babitantes* & $\begin{array}{ll}\text { "Jurisdicción } & \text { de } \\
\text { Santiago" } & \end{array}$ & $\begin{array}{l}\text { (Dr. Omar Jaén Suarez, } \\
\text { 1999) }\end{array}$ \\
\hline 1736 & $\begin{array}{l}30 \text { o } 40 \text { familias, siendo el resto del } \\
\text { vecindario de gente que llamamos } \\
\text { de color y entre unos y otros llegan } \\
\text { a 3,000 almas }\end{array}$ & $\begin{array}{l}\text { informes de la visita } \\
\text { del Obispo Rubio y } \\
\text { Auñon }\end{array}$ & $\begin{array}{l}\text { (Molina Castillo, Mario } \\
\text { José. } \\
\text { 2013) }\end{array}$ \\
\hline 1756 & $\begin{array}{l}\text { 1,227 habitantes. } \\
\text { En el Centro de la ciudad vivian } 792 \\
\text { personas. } \\
\text { En el arrabal y Plaza San Antonio } \\
\text { Vivian } 583 \text { habitantes }\end{array}$ & & $\begin{array}{l}\text { (Molina Castillo, Mario } \\
\text { José. } \\
\text { 2013) }\end{array}$ \\
\hline 1780 & Se triplica la población. & & \\
\hline 1788 & 12,993 babitantes* $^{*}$ & $\begin{array}{l}\text { "Jurisdicción } \\
\text { Santiago" }\end{array}$ & $\begin{array}{l}\text { (Dr. Omar Jaén Suarez, } \\
\text { 1999) }\end{array}$ \\
\hline 1793 & 5,076 babitantes & & $\begin{array}{l}\text { "Compendio de } \\
\text { Historia de Panamá" de } \\
\text { Juan B. Sosa y Enrique } \\
\text { Arce. }\end{array}$ \\
\hline
\end{tabular}

* no comprobado que se hable solo de la ciudad de Santiago de Veraguas, no existe concordancia con otros datos.

Cuadro 3. viviendas del Casco Viejo de la Ciudad de Santiago de Veraguas.

\begin{tabular}{|c|c|c|c|}
\hline año & $\begin{array}{l}\text { Cantidad de viviendas y } \\
\text { características }\end{array}$ & Denominación. & Datos Tomados de \\
\hline 1607 & & $\begin{array}{l}\text { "Jurisdicción de } \\
\text { Santiago" }\end{array}$ & $\begin{array}{l}\text { (Dr. Omar Jaén Suarez, } \\
\text { 1999) }\end{array}$ \\
\hline \multicolumn{4}{|l|}{1607} \\
\hline 1640 & & $\begin{array}{l}\text { "Jurisdicción de } \\
\text { Santiago" }\end{array}$ & $\begin{array}{l}\text { (Dr. Omar Jaén Suarez, } \\
\text { 1999) }\end{array}$ \\
\hline 1691 & & $\begin{array}{l}\text { "Jurisdicción } \\
\text { Santiago" }\end{array}$ & $\begin{array}{l}\text { (Dr. Omar Jaén Suarez, } \\
\text { 1999) }\end{array}$ \\
\hline 1734 & 200 viviendas & & $\begin{array}{l}\text { (Molina Castillo, Mario } \\
\text { José. } \\
\text { 2013) }\end{array}$ \\
\hline 1736 & & $\begin{array}{l}\text { "Jurisdicción de } \\
\text { Santiago" }\end{array}$ & $\begin{array}{l}\text { (Dr. Omar Jaén Suarez, } \\
\text { 1999) }\end{array}$ \\
\hline 1736 & 150 casas & $\begin{array}{l}\text { informes de la visita } \\
\text { del Obispo Rubio y } \\
\text { Auñon }\end{array}$ & $\begin{array}{l}\text { (Molina Castillo, Mario } \\
\text { José. } \\
\text { 2013) }\end{array}$ \\
\hline
\end{tabular}


Invest. pens. crit. (ISSN 1812-3864)

Vol. 7, No. 1, enero- abril 2019

pp. $52-85$

\begin{tabular}{|c|c|c|c|}
\hline \multirow[t]{2}{*}{1756} & $\begin{array}{l}211 \text { viviendas } \\
\text { Centro de la ciudad de Santiago } \\
\text { existían } 82 \text { casas en la plaza y sus } \\
\text { calles. Las casas eran bajas de } \\
\text { madera cercadas de quincha y } \\
\text { cubierta de teja, con } 5 \text { casa de un } \\
\text { alto. Entre el arrabal y Plaza de } \\
\text { San Antonio y sus contornos } \\
\text { había } 129 \text { casas, } 11 \text { de tejas y } 128 \\
\text { casas de paja. }\end{array}$ & & $\begin{array}{l}\text { (Molina Castillo, Mario } \\
\text { José. } \\
\text { 2013) }\end{array}$ \\
\hline & $\begin{array}{l}21 \text { de estas vacías eran casas bajas } \\
\text { de madera, cercadas de quincha y } \\
\text { techadas en teja o de paja. }\end{array}$ & & \\
\hline 1776 & $\begin{array}{l}179 \text { casas, se habían demolido o } \\
\text { abandonado } 32 \text { casas por motivo } \\
\text { de las } \\
\text { emigraciones }\end{array}$ & & $\begin{array}{l}\text { (Molina Castillo, Mario } \\
\text { José. } \\
\text { 2013) }\end{array}$ \\
\hline \multicolumn{4}{|c|}{ ( 0} \\
\hline 1788 & & $\begin{array}{l}\text { "Jurisdicción de } \\
\text { Santiago" }\end{array}$ & $\begin{array}{l}\text { (Dr. Omar Jaén Suarez, } \\
\text { 1999) }\end{array}$ \\
\hline 1793 & $\begin{array}{l}\text { las casas eran de quincha, } \\
\text { embarradas o de tablas y bohíos de } \\
\text { paja. Aunque algunos residentes } \\
\text { construyeron casonas con amplios } \\
\text { portales empedrados y casas de un } \\
\text { alto. Se usan nuevas técnicas } \\
\text { constructivas, diseños y nuevos } \\
\text { materiales. }\end{array}$ & & $\begin{array}{l}\text { "Compendio de } \\
\text { Historia de Panamá" de } \\
\text { Juan B. Sosa y Enrique } \\
\text { Arce. }\end{array}$ \\
\hline
\end{tabular}


Invest. pens. crit. (ISSN 1812-3864)

Vol. 7, No. 1, enero- abril 2019

pp. $52-85$

Cuadro 4. Algunas edificaciones del Casco Viejo de la Ciudad de Santiago de Veraguas en el Siglo XVII.

\begin{tabular}{|l|l|l|l|}
\hline Siglo & edificaciones y características & Posición & $\begin{array}{l}\text { Datos } \\
\text { Tomados } \\
\text { de }\end{array}$ \\
\hline XVII & $\begin{array}{l}\text {-Se Construye El Templo, (En 1636) } \\
\text {-Se Reconstruye El Templo, (En 1637) demolido en } \\
\text { 1938. } \\
\text {-La primera construcción de un Hospital en la ciudad } \\
\text { (Hospital San Juan de Dios), el principal gestor de estas } \\
\text { obras es el Lic. Martin Delgado y Llanos cura vicario. } \\
\text { Calvario. Hoy } \\
\text { Avenida } \\
\text { Central. } \\
\text { actual } \\
\text { posición de la } \\
\text { Biblioteca } \\
\text { Pública y la } \\
\text { Cooperativa } \\
\text { Juan XXIII. }\end{array}$ & $\begin{array}{l}\text { Marió } \\
\text { José. } \\
\text { Castlo, }\end{array}$ \\
& $\begin{array}{l}\text { La Calle Del } \\
\text {-se realiza el trazado de las principales calles y plazas. } \\
\text { (1637). } \\
\text {-Calle Real, hoy Calle Segunda, (En 1637) } \\
\text {-Calle del Calvario, Hoy Avenida Central (En 1637) } \\
\text {-Se crea la Plaza Mayor (en el área del actual Parque Juan } \\
\text { Demóstenes Arosemena) (En 1637) }\end{array}$ & \\
\end{tabular}

Cuadro 5. Algunas edificaciones del Casco Viejo de la Ciudad de Santiago de Veraguas en el Siglo XVIII.

\begin{tabular}{|c|c|c|c|}
\hline Siglo & edificaciones y características & Posición & $\begin{array}{l}\text { Datos } \\
\text { Tomados } \\
\text { de }\end{array}$ \\
\hline XVIII & $\begin{array}{l}\text {-Residencia del Sargento Paulino Villareal tenía una casa } \\
\text { de paja en Santiago de Veraguas y otra en San José de } \\
\text { Montijo. (1720) desaparecida. } \\
\text { - la casa del Dr. José de Urriola Echeverría. (1734) } \\
\text { desaparecida. - residencia del Capitán José Del Águila, } \\
\text { (1770) desaparecida, muy amplia y confortable, con } \\
\text { esmerados trabajos en carpintería y albañilería y } \\
\text { arquitectura con fuerte influencia hispano-musulmán. } \\
\text { Construida en un solar de } 25 \text { varas de frente ( } 21 \text { metros) } \\
\text { y } 30 \text { varas de fondo ( } 25 \text { metros) } 750 \text { varas cuadradas, es } \\
\text { decir } 526 \text { m2. Esta casa era grande de arquitectura } \\
\text { criolla, con amplios portales empedrados en el frente del } \\
\text { patio de las casas. Tenía } 4 \text { ventanas grandes con sus } \\
\text { puertas y } 4 \text { ventanas chicas, una puerta grande que daba } \\
\text { a la calle con llave con excelentes trabajos de carpintería. }\end{array}$ & $\begin{array}{l}\text {-Calle Real } \\
\text { hoy } \\
\text { Calle Segunda } \\
\text {-Calle Real hoy } \\
\text { Calle Segunda } \\
\text {-Calle Real } \\
\text { hoy } \\
\text { Calle Segunda }\end{array}$ & $\begin{array}{l}\text { Molina } \\
\text { Castillo, } \\
\text { Mario } \\
\text { José. } \\
\text { 2013) } \\
\text { (Molina } \\
\text { Castillo, } \\
\text { Mario } \\
\text { José. } \\
\text { 2013) } \\
\text { (Molina } \\
\text { Castillo, } \\
\text { Mario } \\
\text { José. } \\
\text { 2013) }\end{array}$ \\
\hline
\end{tabular}




\begin{tabular}{|c|c|c|}
\hline $\begin{array}{l}\text { Los pisos eran pavimentados con ladrillo, tenía } \\
\text { cielorraso entablado que evitaba que se viera el } \\
\text { encañado y daba mejor apariencia. Las paredes eran } 74 \\
\text { varas de pared de tierra y paja, acaladas mezcla de cal y } \\
\text { arena, repello que daba una buena vista. (desaparecida.) }\end{array}$ & & \\
\hline $\begin{array}{l}\text {-la residencias de Pablo Montero. (desaparecida.) } \\
\text {-la residencia de Catharina de Armengol. (desaparecida.) } \\
\text {-Las residencias de León Guerrero propietario de dos } \\
\text { casa en la Calle San Juan de Dios, de tejas, madera y } \\
\text { paredes de quincha. } \\
\text {-las residencias de Marcos Macías y doña María Jesús } \\
\text { Guerra, además de dos casas de madera y tejas de dos } \\
\text { lumbres cada una. } \\
\text { (desaparecida.) } \\
\text { - En 1759 Se construye la nueva Casa Capitular } \\
\text { (Cabildo) y la nueva Cárcel, hechas de adobe, ladrillos y } \\
\text { tejas. Con cierta expresión artísticas. Promovido por el } \\
\text { Gobernador Félix Francisco Bejarano. con medidas de } \\
40 \text { varas de fachada (33.50 metros), se hacen los } \\
\text { cimientos en piedra y cal, paredes de ladrillo, adobes } \\
\text { cocidos y cal. El techado con las mejores maderas y } \\
\text { techo de tejas. La casa sería utilizada para albergar } \\
\text { visitantes y oficiales. } \\
\text {-Se construye una carnicería. Hechas de adobe, ladrillos } \\
\text { y tejas. (1759.) desaparecida. } \\
\text { - Se crea la Plaza San Juan De Dios. (1759). } \\
\text {-Plazoleta de San Antonio (1759). Desaparecida. } \\
\text { - Ermita de San Antonio (1759). Desaparecida. } \\
\text { - } 2 \text { viviendas del presbítero Francisco Javier de } \\
\text { Vega una cerca de la ermita con una casa cañón y la otra } \\
\text { en la esquina de esta ermita. Las viviendas cerca de esta } \\
\text { ermita San Antonio de Padua la mayoría eran de paja y } \\
\text { quincha y algunas con techo de tejas y de madera con } \\
\text { techo de tejas. (desaparecida.) } \\
\text { - En } 1768 \text { se reconstruye el Hospital San Juan de } \\
\text { Dios en la ciudad de Santiago, al lado de la Iglesia San }\end{array}$ & $\begin{array}{l}\text { Alle San Juan de } \\
\text { Dios. } \\
\text {-La Calle Del } \\
\text { Calvario. } \\
\text {-parte norte de } \\
\text { La } \\
\text { Plaza Mayor } \\
\text { actual Parque } \\
\text { Juan } \\
\text { Demóstenes } \\
\text { Arosemena } \\
\text { - Posición } \\
\text { desconocida. } \\
\text {-Plaza de San } \\
\text { Juan de Dios } \\
\text {-Plazoleta de } \\
\text { San Antonio. }\end{array}$ & $\begin{array}{l}\text { (Molina } \\
\text { Castillo, } \\
\text { Mario } \\
\text { José. } \\
\text { 2013) } \\
\\
\\
\text { (Molina } \\
\text { Castillo, } \\
\text { Mario } \\
\text { José. } \\
\text { 2013) } \\
\\
\text { (Molina } \\
\text { Castillo, } \\
\text { Mario } \\
\text { José. } \\
\text { 2013) }\end{array}$ \\
\hline
\end{tabular}


Invest. pens. crit. (ISSN 1812-3864)

Vol. 7, No. 1, enero- abril 2019

pp. $52-85$

\begin{tabular}{|c|c|c|}
\hline $\begin{array}{l}\text { Juan De Dios (Santa Bárbara) la misma posición del } \\
\text { antiguo Hospital. Con materiales más resistentes. Por } \\
\text { primera vez se utiliza una planta arquitectónica para } \\
\text { construir un proyecto, dicha planta tenia también varias } \\
\text { secciones para la mejor compresión de la obra, estaba a } \\
\text { una escala de } 100 \text { varas castellanas. El } 14 \text { de febrero de } \\
1770 \text { se inaugura el Hospital San Juan de Dios y la Iglesia } \\
\text { Santa Bárbara frente a la Plaza San Juan de Dios. }\end{array}$ & $\begin{array}{l}\text { Pública y la } \\
\text { Cooperativa } \\
\text { Juan XXIII. } \\
\text {-La Calle Del } \\
\text { Calvario. } \\
\text { Hoy Avenida } \\
\text { Central. }\end{array}$ & $\begin{array}{l}\text { (Molina } \\
\text { Castillo, } \\
\text { Mario } \\
\text { José. 2013) }\end{array}$ \\
\hline $\begin{array}{l}\text {-por mandato del Gobernado Francisco Matos (1793 - } \\
\text { 1797) la Casa de Gobernadores, frente al Hospital San } \\
\text { Juan de Dios construida de barro, tabla y teja y otra casa } \\
\text { de su propiedad, para alojamiento llamada } \\
\text { Galería, donde se alojaban por lo general trabajadores de } \\
\text { las minas. }\end{array}$ & & \\
\hline
\end{tabular}

Cuadro 6. Algunas edificaciones del Casco Viejo de la Ciudad de Santiago de Veraguas en el Siglo XIX.

\begin{tabular}{|l|l|l|l|}
\hline Siglo & edificaciones y características & Posición & $\begin{array}{l}\text { Datos } \\
\text { Tomados } \\
\text { de }\end{array}$ \\
\hline XIX & & & $\begin{array}{l}\text { (Dr. Omar } \\
\text { Jaén } \\
\text { Suarez, } \\
1999)\end{array}$ \\
\hline
\end{tabular}

Cuadro 7. Algunas edificaciones del Casco Viejo de la Ciudad de Santiago de Veraguas en el Siglo XX.

\begin{tabular}{|l|l|l|l|}
\hline Siglo & edificaciones y características & Posición & $\begin{array}{l}\text { Datos } \\
\text { Tomados } \\
\text { de }\end{array}$ \\
\hline $\mathrm{XX}$ & & & $\begin{array}{l}\text { (Dr. Omar } \\
\text { Jaén } \\
\text { Suarez, } \\
1999)\end{array}$ \\
\hline
\end{tabular}


Invest. pens. crit. (ISSN 1812-3864)

Vol. 7, No. 1, enero- abril 2019

pp. $52-85$

Cuadro 8. Algunas edificaciones del Casco Viejo de la Ciudad de Santiago de Veraguas en el Siglo XX.

\begin{tabular}{|l|l|l|l|}
\hline Siglo & edificaciones y características & Posición & $\begin{array}{l}\text { Datos } \\
\text { Tomados } \\
\text { de }\end{array}$ \\
\hline XXI & 200 viviendas & & (Molina \\
& & & $\begin{array}{l}\text { Castillo, } \\
\text { Mario } \\
\text { José. } \\
\text { 2013) }\end{array}$ \\
\hline
\end{tabular}

\section{Notas.}

El resultado de esta investigación se fundamentó mediante el trabajo de campo, la revisión de fuentes bibliográficas y documentación en archivos. Se emplearon métodos teóricos: históricológico, sistémico-estructural y análisis-síntesis; y el método empírico: observación de la realidad.

Se analizaron variables de otras ramas, aparte de la arquitectura y planeamiento urbano, que apoyaron esta investigación, para identificar el problema tratado. La metodología y las variables de estudio, se definieron, para caracterizar de la arquitectura Histórico Urbana de Santiago de Veraguas, objetivo principal de la investigación, partió de un análisis integral que contempló el marco histórico en que surge y se desarrolla la arquitectura y urbanismo en el contexto nacional y local, el estudio de los referentes historiográficos relacionados con el tema, los aspectos de carácter teórico-metodológico (las metodologías de análisis de la arquitectura), los criterios sobre estudios tipológicos y las aportaciones del medio geográfico en que se enclava el objeto de estudio.

Se Utilizaron métodos tradicionales como de vanguardia como:

- Incorporación del uso de aplicaciones informáticas y herramientas en línea que permitieron automatizar procesos tediosos de búsqueda y gestión bibliográfica.

- Revisión crítica, de artículos de investigación y lecturas existentes.

- Encuestas a residentes de estas áreas, instituciones estatales y demás.

- Revisión de estadísticas existentes y aplicándolas al problema en investigación.

- Utilización de métodos gráficos para resultados de los datos.

- Trabajo analítico con el estudio de los planos y mapas desde inicios de la fundación de la ciudad hasta la fecha.

- Revisión de aspectos metodológicos de proyectos ya realizados dentro del área o en otras ramas. 
Invest. pens. crit. (ISSN 1812-3864)

Vol. 7, No. 1, enero- abril 2019

pp. $52-85$

Revisión de publicaciones donde suelen difundirse los resultados de investigación y la producción académica o artística de los profesionales del área.

En la bibliografía consultada, hemos encontrado, algunos temas como la definición del período general de desarrollo, así como etapas evolutivas vinculadas a los factores de orden socioeconómico y cultural en cada contexto, diversidad de temas arquitectónicos.

Asimilación de códigos por las distintas clases sociales, relacionados con las tipologías constructivas llevadas a cabo, tanto por profesionales como por constructores y usuarios.

Se realizaron el análisis de las obras en el orden de lo formal, y en menor medida de lo técnicoconstructivo y lo funcional. En estos estudios formales se menciona la volumetría ceñida a los planos de fachada, y definida en este caso por los elementos decorativos a relieve. Los patrones de estéticos de la arquitectura tienen incidencia directa y transforman esencialmente la expresión formal, reflejada tanto en interiores como en exteriores.

Tomamos en consideración los elementos decorativos, las terminaciones, la herrería, elementos componentes como pilastras adosadas, la carpintería y la forma del remate; y En los interiores: los pisos, la iluminación, el color, el revestimiento de los muros, el diseño de las escaleras y la ornamentación. Lo referido anteriormente se muestra compatible con las metodologías empleadas en otros análisis tipológicos, tanto teóricos como aplicados específicamente a un caso de estudio. Destacamos el estrecho vínculo entre los estilos y el medio geográfico, lo que puede generar estilos y tipologías regionales.

Otra metodología planteada de forma general que el análisis se dirigió hacia la comprensión global de los fenómenos arquitectónicos, considerados como un todo coherente, donde deben concebirse los sistemas arquitectónicos y urbanos en su desarrollo histórico concreto, ubicado en tiempo y espacio y condicionados por los diversos factores que caracterizan la sociedad y el contexto físico en el cual se insertan. De esta forma, se trazó una estructura flexible que parte de considerar los factores socioculturales y socioeconómicos definidos por el contexto espaciotemporal donde se generó la obra, hasta determinar su significación cultural y su apreciación dentro de la cultura arquitectónica. Para ello se valió de leyes y principios dictados por el materialismo histórico y dialéctico, ellos son: el principio de los sistemas, el principio de los factores condicionantes, el principio del proceso de diseño, el principio de la significación, y el principio de la relación en arquitectura entre el pensamiento lógico-científico y el estructurado en imágenes.

Se tomó en cuenta paralelamente la singularidad aportada por la geografía del sitio; entiéndase la incidencia de la topografía de la ciudad en las edificaciones; la ubicación del asentamiento sobre fallas tectónicas de considerable importancia y su efecto en la conformación de la arquitectura; por último, el hálito caribeño impreso en la ciudad y sus habitantes, y su relación con las propuestas arquitectónicas.

Durante la investigación se definieron tres grupos funcionales:

a) Edificios públicos. 
Invest. pens. crit. (ISSN 1812-3864)

Vol. 7, No. 1, enero- abril 2019

pp. $52-85$

b) Edificios de vivienda.

c) Edificios Religiosos.

Del análisis de la problemática que enfrentan estas edificaciones en dicho contexto permitió agrupar posibles causas que inciden en la pérdida de integridad, entre ellas:

- La persistencia de prejuicios hacia el patrimonio arquitectónico del siglo XX, dada su amplia proliferación y cercanía en el tiempo, considerándose en mayor medida el aporte del período colonial a la identidad local y regional.

- Incorrecta apreciación y desconocimiento de los valores estético, histórico, cultural y ambiental de esta arquitectura, debido a la expresión modesta asumida en correspondencia con la clase media y proletaria que asimiló estos códigos.

- Limitada tutela y manejo del patrimonio arquitectónico por parte de los organismos del territorio.

Tomando en cuenta los aspectos planteados con anterioridad, la situación problemática consiste en:

- La necesidad de profundizar en los estudios acerca del patrimonio arquitectónico en la ciudad de Santiago de Veraguas, para completar los vacíos existentes en la historiografía arquitectónica local.

\section{Referencia bibliográfica}

FABIÁN GARRÉ, 2001. Patrimonio arquitectónico urbano, preservación y rescate: bases conceptuales e instrumentos de salvaguarda. Revista Conserva 2001.

FRANCESC CABALLÉ I ESTEVE, 2003. Arquitectura y Documentación: arqueología de la vivienda en el Casco Antiguo de Barcelona. Revista Scripta Nova, 1 de Agosto de 2003.

GROUT, LINDA N., WANG, DAVIS (2010). Architectural Research Methods, Second Edition. EEUU.

ANDRZEJ WYROBSZ, Ordenanza de Felipe II del año 1573 y la construcción de ciudades coloniales españolas en la América,

JORGE GONZÁLEZ ARAGÓN Y EVERARDO CARBALLO CRUZ, Arquitectura y urbanismo militar en Iberoamérica.

MAYRA MONCADA Y JOSÉ OMAR, Cartografía española en América durante el siglo XVIII, Recopilación de las leyes de las Indias, Archivo general de las indias, Archivo general de Simancas

CARMEN MENA GARCÍA, Panamá en el siglo XVIII, trazado urbano, materiales y técnicas constructivas

REYNA TORRES DE ARAUZ, Antologías de la ciudad de Panamá tomo I.

TEJEIRA DAVIS, EDUARDO. Colonialismo- sincretismo y adaptación al trópico.

TEJEIRA DAVIS, EDUARDO. Casco Antiguo Panamá.

ALFREDO CASTILLERO CALVO, estructuras sociales y económicas de Veragua desde 
Invest. pens. crit. (ISSN 1812-3864)

Vol. 7, No. 1, enero- abril 2019

pp. $52-85$

sus orígenes históricos siglo XVI y XVII y la otra,

ALFREDO CASTILLERO CALVO, conquista evangelización y resistencia.

Hombre y Cultura 1966, del Centro de Investigación Antropológica de la Universidad de

Panamá

Cronologías de los pueblos y ciudades del istmo, Centro de Investigación Antropológica de la Universidad de Panamá.

MARIO JOSÉ MOLINA CASTILLO, Veragua: Tierra de Colon y de Urraca Tomo I Y II.

RICAURTE ARROCHA, Antecedentes históricos y detalles del tesoro Colonial de la iglesia de San Francisco de la Montaña,

SAMUEL GUTIÉRREZ, 1979, El arte Barroco de la Iglesia de San Francisco de la Montaña MARÍA

BERENICE RUIZ, Trazos históricos de San Francisco de Veraguas, ALBERTO OSORIO OSORIO, Santiago de Veraguas Colonial.

MAGISTER SARA DE TROETSH, Sociedad Rural y Guerra Civil, Veraguas en la Guerra de los Mil Días.

PEDRO J. MÉRIDA, PEDRO J., Por los predios de Urracá,

ALFREDO CASTILLERO CALVO, Estructuras Sociales y Económicas de Veraguas desde sus Orígenes Históricos Siglo XVI, XVII.

SAMUEL GUTIÉRREZ, La Ciudad de Panamá y la primera Modernidad,

SAMUEL GUTIÉRREZ, Plástica Urbana.

EDUARDO TEJEIRA DAVIS, Arquitectura del Canal de Panamá.

NICOLÁS CABALLERO Síntesis Histórica de Santiago de Veraguas,

REGINALDO MACÍAS, Recuerdos de antaño en mi pueblo natal, Santiago de Veraguas.

VICENTE CABALLERO D., Senderos y Reflexiones y de Ismael Valdés, Remembranzas de mi pueblo.

CLAUDIO ATENCIO, Información de la Provincia de Veraguas IPAT.

Informe de la Diócesis de Veraguas, 1964-1989,

ALFREDO MORÍN C, Historia Pastoral de La Iglesia de Panamá. I La Iglesia Colonial. Revista de Santiago Ayer, hoy Ilustrado, confeccionado por Foto 2 mil. 